\section{Pacific Northwest}

National Laboratory

Operated by Battelle for the

U.S. Department of Energy

\title{
Dissolution Kinetics of Titanate-Based \\ Ceramic Waste Forms: Results from Single-Pass Flow Tests on Radiation Damaged Specimens
}

\author{
J. P. Icenhower \\ E. A. Rodriguez \\ D. M. Strachan \\ J. L. Steele \\ M. M. Lindberg
}

May 2003

Prepared for the U.S. Department of Energy

under Contract DE-AC06-76RL01830 


\title{
DISCLAIMER
}

This report was prepared as an account of work sponsored by an agency of the United States Government. Neither the United States Government nor any agency thereof, nor Battelle Memorial Institute, nor any of their employees, makes any warranty, express or implied, or assumes any legal liability or responsibility for the accuracy, completeness, or usefulness of any information, apparatus, product, or process disclosed, or represents that its use would not infringe privately owned rights. Reference herein to any specific commercial product, process, or service by trade name, trademark, manufacturer, or otherwise does not necessarily constitute or imply its endorsement, recommendation, or favoring by the United States Government or any agency thereof, or Battelle Memorial Institute. The views and opinions of authors expressed herein do not necessarily state or reflect those of the United States Government or any agency thereof.

\author{
PACIFIC NORTHWEST NATIONAL LABORATORY \\ operated by \\ BATTELLE \\ for the \\ UNITED STATES DEPARTMENT OF ENERGY \\ under Contract DE-AC06-76RL01830
}

This document was printed on recycled paper. 


\title{
Dissolution Kinetics of Titanate-Based Ceramic Waste Forms: Results from Single-Pass Flow Tests on Radiation Damaged Specimens
}

\author{
J. P. Icenhower \\ D. M. Strachan \\ M. M. Lindberg \\ E. A. Rodriguez \\ J. L. Steele
}

May 2003

Prepared for the U.S. Department of Energy

under Contract DE-AC06-76RL01830

Pacific Northwest National Laboratory

Richland, Washington 99352 


\section{Summary}

In this report, we summarize the results of our single-pass flow-through (SPFT) tests on titanate ceramics at Pacific Northwest National Laboratory. These titanate ceramics are candidate disposal forms for excess weapons plutonium that is obligated by treaty to be immobilized. The main conclusion of this investigation is that radiation-damaged titanate waste forms dissolve at the same rate $\left[3.2 \cdot 10^{-4} \mathrm{~g} /\left(\mathrm{m}^{2} \cdot \mathrm{d}\right)\right]$ as fully crystalline materials. These data are consistent with the proposition that radiation damage, even to the extent that the ceramic becomes amorphous, does not affect the dissolution rate significantly.

The dissolution kinetics of the primary phases in the ceramic immobilization form, pyrochlore, zirconolite, and brannerite, were determined at $90^{\circ} \mathrm{C}$ and over the $\mathrm{pH}$ values 2 to 11 . Specimens containing ${ }^{238} \mathrm{Pu}$ (crystalline and amorphous), ${ }^{239} \mathrm{Pu}$, or $\mathrm{CeO}_{2}$ (as a surrogate for $\mathrm{Pu}$ ) were tested. Damage from self-irradiation was caused by the decay of ${ }^{238} \mathrm{Pu}$. To directly compare the corrosion resistance of these materials over a broad range of simulated ages, fully damaged and recrystallized (resintered) specimens were studied. By manipulating input solution flowrate, $q$, and the sample surface area, $S$, experiments were performed over a wide range of solution saturation values. The data from the nonradioactive tests clearly demonstrate that as the solution contacting the solids becomes dilute, the dissolution rate becomes independent of $q / S$ values above $10 \mathrm{e}-8\left(\mathrm{~m} \mathrm{~s}^{-1}\right)$. The forward release rates quantified for each material are $6.3 \cdot 10^{-3}, 1.6 \cdot 10^{-3}, 1.3 \cdot 10^{-3}$, and $2 \cdot 10^{-4} \mathrm{~g} /\left(\mathrm{m}^{2} \cdot \mathrm{d}\right)$ for brannerite, zirconolite, pyrochlore-based baseline, and pyrochlore ceramics, respectively; these are extremely low release rates. These results can be used to model the long-term reactivity of titanate waste forms for conditions germane to a prospective geologic repository. 



\section{Contents}

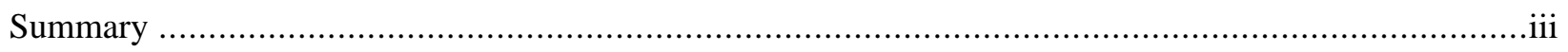

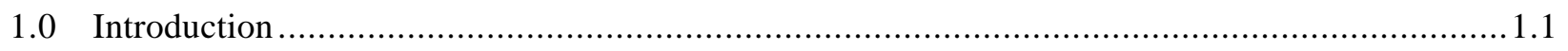

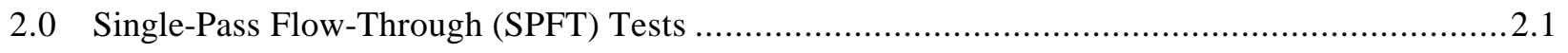

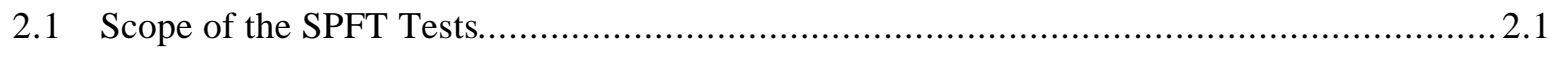

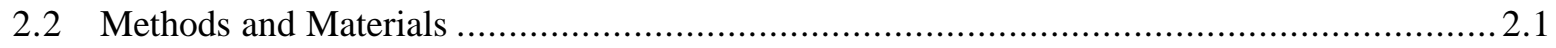

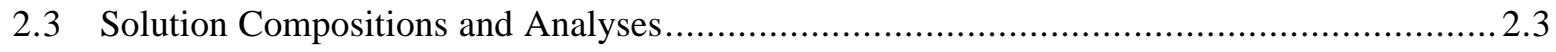

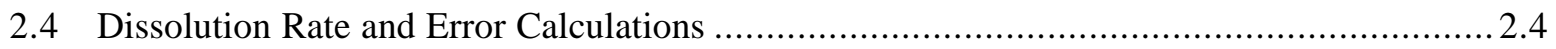

2.5 Chemical Compositions of the Titanate Ceramics ............................................... 2.5

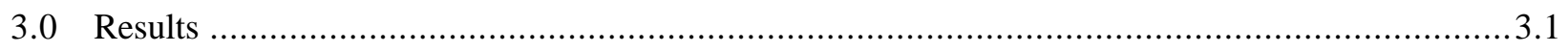

3.1 Dependence of Reaction Rate on Flowrate........................................................ 3.1

3.2 Dissolution Rates of ${ }^{238} \mathrm{Pu}$-Bearing Ceramics ........................................................ 3.3

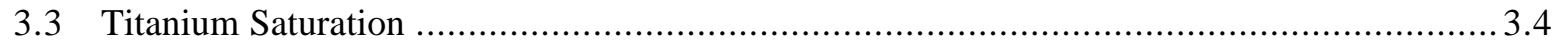

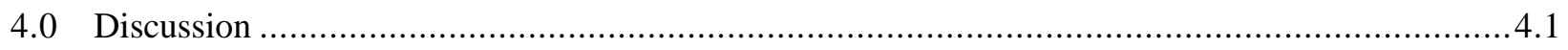

4.1 Influence of Radiation Damage on Titanate Dissolution Rates .................................. 4.1

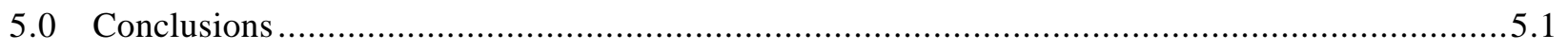

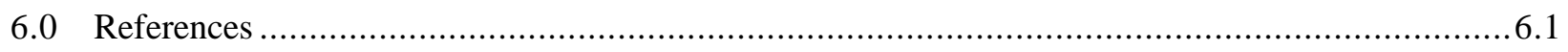

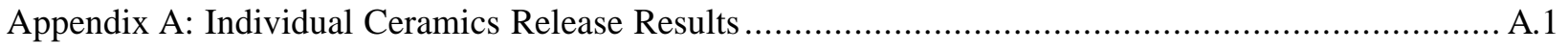




\section{Figures}

2.1. Schematic of the Single-Pass Flow Apparatus for Testing Corrosion Resistance of Titanate Ceramics

3.1. Plot of the Dissolution Rate Versus the Flowrate to Surface Area (q/S) Ratio for Zirconolite Powders and Monoliths at $90^{\circ} \mathrm{C}, \mathrm{pH}=2$. Zr-6, HZ-6X, and $\mathrm{ZZ}$ refer to specimens from individual batches of material; there is no difference in bulk chemistry between them. The non-linear regression indicates a $\log$ [forward rate $\left(\mathrm{g} \mathrm{m}^{-2} \mathrm{~d}^{-1}\right)$ ] of -2.81

3.2. Plot Log Dissolution Rate Versus Log $\mathrm{q} / \mathrm{S}$ for Data from Experiments with Pyrochlore-Rich Baseline and Pure Phase Pyrochlore Specimens. All data were collected at $90^{\circ} \mathrm{C}$ and $\mathrm{pH}=2$ solutions. The horizontal lines mark the apparent forward rate of reaction.

3.3. Plot of the Concentration of Gd Versus Time for the Three Experiments Containing ${ }^{238} \mathrm{Pu}$ and the ${ }^{239} \mathrm{Pu}$ Zirconolite Specimens.

3.4. Plot of the Concentration of $\mathrm{U}$ and $\mathrm{Pu}$ Versus Time for the Three Experiments Containing ${ }^{238} \mathrm{Pu}$ and the ${ }^{239} \mathrm{Pu}$ Zirconolite

3.5. Plot of Ti Concentration of Effluent Samples from Dissolution Experiments on Pyrochlore, Pyrochlore-Rich Baseline, and Zirconolite at $90^{\circ} \mathrm{C}$ and $\mathrm{pH}=2$. The $100^{\circ} \mathrm{C} \mathrm{TiO}_{2}$ saturation concentration is displayed as the dashed line (Knauss et al. 2001). 


\section{Tables}

2.1. Chemical Compositions Used in SPFT Experiments. Solution $\mathrm{pH}$ values at $90^{\circ} \mathrm{C}$ were calculated with EQ3NR Code V7.2b database (Wolery 1992b).....

2.2. Chemical Compositions (in mass\%) of Titanate Ceramics

\section{Appendix A Tables}

A.1. Experimental Conditions and Steady-State Effluent Concentrations of Dissolved Elements for Tests with "Pure-Phase" Pyrochlore Ceramics

A.2. Experimental Conditions and Steady-State Effluent Concentrations of Dissolved Elements for Tests with Pyrochlore Baseline ("P-Base") Ceramics.

A.3. Experimental Conditions and Steady-State Effluent Concentrations of Dissolved Elements for Tests with Brannerite Ceramics.

A.4. Experimental Conditions and Steady-State Effluent Concentrations of Dissolved Elements for Tests with Pyrochlore Ceramics

A.5. Experimental Conditions and Steady-State Effluent Concentrations of Dissolved Elements for Tests with Pyrochlore Baseline Ceramics.....

A.6. Experimental Conditions and Steady-State Effluent Concentrations of Dissolved Elements for Tests with Zirconolite Ceramics

A.7. Experimental Conditions and Steady-State Effluent Concentrations of Dissolved Elements for Tests with ${ }^{238} \mathrm{Pu}$-Bearing Pyrochlore Baseline Ceramics

A.8. Experimental Conditions and Steady-State Effluent Concentrations of Dissolved Elements for Tests with Zirconolite Ceramics

A.9. Experimental Conditions and Steady-State Effluent Concentrations of Dissolved Elements for Tests with ${ }^{239} \mathrm{Pu}$-Bearing Zirconolite Ceramics

A.10. Experimental Conditions and Steady-State Effluent Concentrations of Dissolved Elements for Tests with ${ }^{238} \mathrm{Pu}$-Bearing Pyrochlore Baseline (annealed and un-annealed), Pyrochlore, and Zirconolite Ceramics

A.11.Experimental Conditions and Steady-State Effluent Concentrations of Dissolved Elements for Tests with ${ }^{239} \mathrm{Pu}$-Bearing Pyrochlore Baseline ("P-Base") Ceramics

A.12. Steady-State Dissolution Rates and Associated 1 $\sigma$-Error for "Pure Phase" Pyrochlore Ceramics . A.7

A.13. Steady-State Dissolution Rates and Associated 16-Error for Pyrochlore Baseline Ceramics A.8 
A.14. Steady-State Dissolution Rates and Associated 1 $\sigma$-Error for Brannerite Ceramics

A.15. Steady-State Dissolution Rates and Associated 1 $\sigma$-Error for "Pure-Phase" Pyrochlore Ceramics . A.9

A.16. Steady-State Dissolution Rates and Associated 16-Error for Pyrochlore Baseline Ceramics ...... A.10

A.17. Steady-State Dissolution Rates and Associated 1 $\sigma$-Error for Zirconolite Ceramics.................. A.10

A.18. Steady-State Dissolution Rates and Associated $1 \sigma$-Error for ${ }^{238} \mathrm{Pu}$-Bearing Pyrochlore

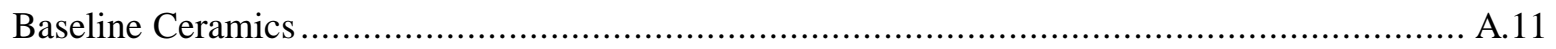

A.19. Steady-State Dissolution Rates and Associated 16-Error for Zirconolite Ceramics................... A.11

A.20. Steady-State Dissolution Rates and Associated $1 \sigma$-Error for ${ }^{239} \mathrm{Pu}$-Bearing

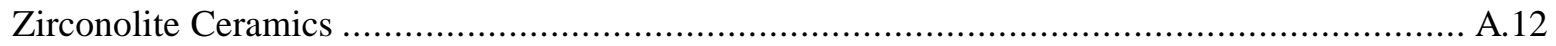

A.21. Steady-State Dissolution Rates and Associated $1 \sigma$-Error for ${ }^{238} \mathrm{Pu}$-Bearing Pyrochlore Baseline (annealed and un-annealed), "Pure Phase" Pyrochlore, and Zirconolite Ceramics........ A.12

A.22. Steady-State Dissolution Rates and Associated $1 \sigma$-Error for ${ }^{239} \mathrm{Pu}$-Bearing Pyrochlore

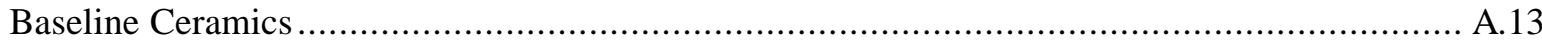




\subsection{Introduction}

Titanate-based ceramics emerged as the leading candidate for a matrix for disposal of excess weaponsgrade plutonium in a deep geologic repository (Cochran et al. 1997). Concerns persisted, however, that the accumulation of radiation damage would compromise the desirable chemical and physical properties of the titanate matrix. To date, the link between self-induced radiation damage from the decay of ${ }^{239} \mathrm{Pu}$ and a modification in the dissolution rate has not been documented. Part of the problem stems from the manner in which experiments were performed that aimed to investigate this effect. In particular, simultaneous measurements of radiation-damaged and undamaged specimens under identical experimental conditions have not been made. Because of the long half-life of ${ }^{239} \mathrm{Pu}$ (half-life: $2.41 \cdot 10^{4} \mathrm{y}$ ), significant radiation damage accumulates too slowly to be measured in the laboratory. On the other hand, including radioisotopes with short half-lives, such as ${ }^{238} \mathrm{Pu}$ (half-life: $87.7 \mathrm{y}$ ), in the candidate materials may prove useful, provided that a careful study of the radiation effects and the change in reaction rate can be quantified. In other studies, investigators have bombarded specimens with heavy ions to produce an $\mathrm{X}$-ray amorphous layer that serves as an analog for material that has undergone radiation damage from an alpha-particle-emitting isotope (Weber et al. 1985; 1986). These studies indicate a maximum increase in the dissolution rate of 10 to $50 \mathrm{X}$ in heavy ion-bombarded materials compared to undamaged materials (Begg et al. 2000). While specimens that have a thin X-ray amorphous layer are useful for limited dissolution tests, the bulk properties, such as radiation-induced swelling, cannot be studied with these specimens.

Another strategy, as indicated above, is to study specimens containing radionuclides with shorter halflives, such as ${ }^{244} \mathrm{Cm}$ or ${ }^{238} \mathrm{Pu}$. With shorter half-lives, there is the prospect that radiation-damage effects can be detected relatively quickly, and element release rates can be compared against samples containing ${ }^{239} \mathrm{Pu}$. More importantly is the fact that the damage occurs throughout the specimen. Therefore, changes in bulk density and dimensions can be studied. However, even in these types of experiments, controversy persists surrounding the relationship between radiation damage and element release rates. For example, the authors of a Japan Atomic Energy Research Institute/Australian Nuclear Science and Technology Organisation (JAERI/ANSTO) report (Report 1999) documented release rates on the order of $10^{-5} \mathrm{~g} /\left(\mathrm{m}^{2} \cdot \mathrm{d}\right)$ for a Synroc composition containing $4 \cdot 10^{-4}$ mass $\% \mathrm{Cm}$. Later experiments with samples containing $\sim 1$ mass $\%{ }^{244} \mathrm{Cm}$ indicated a release rate of $\sim 10^{-3} \mathrm{~g} /\left(\mathrm{m}^{2} \cdot \mathrm{d}\right)$, or a factor of $\sim 100 \mathrm{X}$ higher rate than the sample with lower Cm concentration (Mitamura et al. 1994). However, the relative release rates of other elements, such as $\mathrm{Sr}, \mathrm{Ca}$, and Cs, were approximately the same between the two samples. This is potentially problematic because, without justification, there is no reason to accept one rate value over another, leaving the modeler to choose a "preferred" rate for use in performance-assessment exercises.

In 2001, we reported dissolution rates for ${ }^{238} \mathrm{Pu}$-bearing specimens that were from 80 to 1000 times higher than for the corresponding specimen made with ${ }^{239} \mathrm{Pu}$ (Strachan et al. 2001a). There were at least two possibilities for this difference in rate. The dissolution rate for the damaged material could be greater than the dissolution rate for the undamaged material, or radiolysis products could be building in the solution while in contact with the test specimen. Both interpretations could be used with the data from Strachan et al. (2001a). Therefore, the purpose of the tests reported here is to determine which of these is the reason for the apparently high dissolution rates. To do this, we tested the corrosion resistance of surrogate ceramic waste forms over a wide span of experimental parameters and bulk chemical 
compositions. Both fully crystalline and X-ray amorphous materials were evaluated in a new experimental apparatus in which experimental artifacts were either removed or minimized. 


\subsection{Single-Pass Flow-Through (SPFT) Tests}

\subsection{Scope of the SPFT Tests}

The data discussed in this report center on the quantification of radiation-damage effects to titanate ceramics as manifested by a change in rate between undamaged and damaged specimens. The results of the SPFT tests on nonradioactive specimens (containing no $\mathrm{Pu}$ or $\mathrm{U}$ ) are also reported. A suite of tests on both powdered and monolithic specimens was carried out to determine the dependence of the rate on solution saturation. We achieved different solution saturation states by adjusting the ratio of solution flowrate $\left(q, \mathrm{~m}^{3} \mathrm{~s}^{-1}\right)$ to specimen surface area $\left(S, \mathrm{~m}^{2}\right)$ and denoted as $q / S$. Under dilute conditions the dissolution rates become independent of $q / S$. This condition in which rates are constant, also referred to in the literature as the "rate plateau," is the forward rate of reaction. Obtaining forward rates for the various pyrochlore, pyrochlore-rich baseline, zirconolite, and brannerite ceramics yields the essential data needed by modelers to calculate the release of radionuclides to a solution.

Although a small fraction of the data have appeared in other reports, most of the data contained in this report are new. We also rely to a small extent on the results of complementary experiments on betafite (Ti-rich pyrochlore) ceramics that were obtained under the direction of Dr. W. J. Weber in an Environmental Management Science Program (EMSP) project. As we demonstrate below, the data from the other set of experiments correlate well with those determined for the Plutonium Immobilization Project and serve as a point of discussion and recommendations outlined below.

\subsection{Methods and Materials}

In our initial set of experiments with the ${ }^{238} \mathrm{Pu}$-bearing specimens, we used a modified SPFT apparatus in which Teflon ${ }^{\circledR}$ reaction vessels and fluid exchange lines were used. To modify the Teflon reaction vessel, we added a platinum liner to shield the Teflon from the alpha radiation with the hope of decreasing the release of the fluoride ion from Teflon reactor vessel as a result of the alpha dose from the test specimen. Damage to the Teflon reactor is possible since the powdered specimen rests directly on the bottom of the vessel. The insert was tall enough to protect the interior of the reactor so that the only Teflon in contact with the solution was that associated with the influent and effluent lines. Counter to our expectations, we found that significant (10 to $100 \mathrm{ppm}$ ) concentrations of fluoride were present in effluent solutions from experiments with ${ }^{238} \mathrm{Pu}$-bearing materials. As yet, we are not certain what the source of the fluoride was, but the presence of fluoride in the leachate does not agree with existing theories about the efficiency of alpha radiation on fluoride release from Teflon. Significantly, fluoride has not been detected in any effluent solutions from conjugate experiments with ${ }^{239} \mathrm{Pu}$-bearing specimens. If allowed to stand, the presence of fluoride in the leachates would always cloud the validity of any conclusions we would make on the dissolution of these ceramic materials.

An additional concern surfaced while examining the results from the initial set of tests when we determined that the flowrate was too low. The initial experiments had a flowrate of $\sim 2 \mathrm{~mL}$ per day, which allowed us to use small amounts of ${ }^{238} \mathrm{Pu}$-bearing material while yielding detectable concentrations of analytes in the effluent solutions. However, we also came to the realization that, at these low 
flowrates, the strong radiation field from ${ }^{238} \mathrm{Pu}$ could result in radiolysis products that could affect the dissolution rate and make interpretation of the results difficult. In sum, a new SPFT apparatus was needed in which the leachant neither comes in contact with Teflon nor is in contact with the specimen long enough for significant radiolysis products to accumulate. Accordingly, for the experiments with ${ }^{238} \mathrm{Pu}$-bearing materials, we replaced the Teflon-based system with one based on titanium.

In this new apparatus, the $\sim 20-\mathrm{mL}$ reactor vessel consists of titanium top and bottom pieces that screw together. The volume of the reactor vessel is approximately one-third less than that of the Teflon reactors. This allows us to run high flowrates (ca $20 \mathrm{~mL} / \mathrm{d}$ ) that purge the solution rapidly and keep the concentration of the radiolysis products low and the solution at or near dilute conditions. The top portion of the reactor contains ports for input and effluent lines. The fluid transport lines are constructed from small-bore titanium tubing to decrease the dead volume. A flat gold ring was used to seal the top and bottom halves of the reactor. The experimental arrangement is, in other respects, the same as for the Teflon apparatus (Figure 2.1). Syringe pumps were programmed to yield constant flowrates of solution from the solution reservoir through the SPFT apparatus. As in the case of the Teflon reactors, the powdered sample lies on the bottom of the reactor. This configuration prevented air bubbles from nucleating in pore spaces between powder grains, thereby providing leachate access to the entire specimen surface. The reactor vessel was heated in aluminum-block heating wells with internal resistance elements. However, even with the deployment of insulating materials, the operating temperature was nearly constant at $85^{\circ} \mathrm{C}$, although the target temperature was $90^{\circ} \mathrm{C}$. The reason for this lower temperature was that the Ti SPFT apparatus was in a fume hood, and the rapid exchange of air in the hood effectively removed heat that could not be compensated. Temperatures of the experiments were determined in situ with a calibrated thermocouple.

Experiments with specimens that did not contain ${ }^{238} \mathrm{Pu}$ used the standard SPFT apparatus fashioned from Teflon components. This system served us well when testing the non-radioactive (no $\mathrm{Pu}$ or $\mathrm{U}$ ) and ${ }^{239} \mathrm{Pu}-$ bearing titanate ceramics and, as we show below, the data obtained with the Teflon and titanium reactors yield consistent results. The salient features of the SPFT apparatus used in this study are illustrated in Figure 2.1. Syringe pumps (Kloehn; model 50300) were used to transfer solution from the input reservoir bottles to the reaction vessels. Multiple fluid transfer lines are a key feature of these syringe pumps. Thus, one syringe pump can deliver solution to one to four reactors so that duplicate experiments and blanks can be run simultaneously. Nitrogen gas was used to purge the free space above the leachant in the solution reservoir, thereby

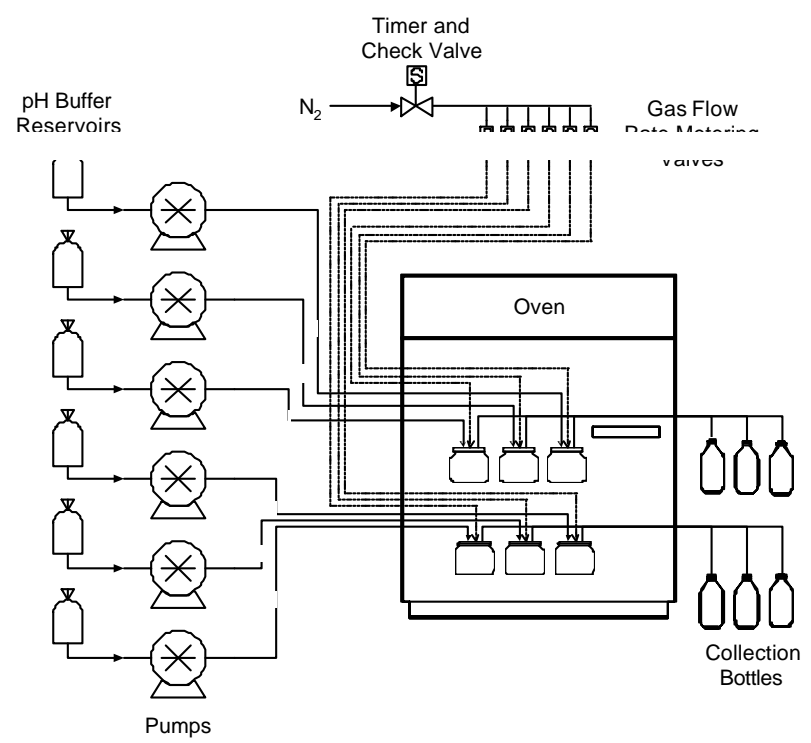

Figure 2.1. Schematic of the Single-Pass Flow Apparatus for Testing Corrosion Resistance of Titanate Ceramics 
mitigating the effect of atmospheric $\mathrm{CO}_{2}$ on the $\mathrm{pH}$ of the leachant.

The temperature of the experiments with the Teflon-based apparatus was kept at $90^{\circ} \mathrm{C}$ in a laboratorygrade oven. A digital thermocouple reader, accurate to $\pm 2{ }^{\circ} \mathrm{C}$, was used to record oven temperature daily. The reactor vessels have lids with two ports through which Teflon tubes pass for solution input and for leachate removal. The powdered ceramic specimen lies at the bottom of the reactor in a thin layer. Effluent was accumulated continuously in collection bottles situated outside the oven.

\subsection{Solution Compositions and Analyses}

The chemical durability of the ${ }^{238} \mathrm{Pu}$-bearing pyrochlore baseline and pure-phase pyrochlore ceramics were tested in $\mathrm{pH}=2$ solutions. The majority of the remaining experiments were conducted at $\mathrm{pH}=2$ solutions as well. Although acidic conditions will not prevail in prospective geologic repositories, $\mathrm{pH} 2$ solutions allow for relatively fast release of elements to solution and also avoid solubility limitations for $\mathrm{Gd}, \mathrm{Ce}$, and $\mathrm{Pu}$. Further, we show in this report, as we have in the past (Strachan et al. 2001a), that there is a weak $\mathrm{pH}$-dependence of the dissolution rate. Therefore, at worst, the forward dissolution rate at $\mathrm{pH} 2$ is about a factor of 10 higher than the forward dissolution rate at neutral to slightly alkaline $\mathrm{pH}$ values.

Six solutions at $\mathrm{pH}$ values of $2,7,8,9,10$, and 11 were used for the experiments with ${ }^{239} \mathrm{Pu}$-bearing pyrochlore baseline and the non-radioactive zirconolite ceramics. Reagent grade nitric acid was mixed with deionized water to yield acidic solution $(\mathrm{pH}=2)$. Neutral to slightly basic solutions $(\mathrm{pH}=7,8,9$, and 10) were made by mixing small amounts of the organic THAM (tris hydroxymethyl aminomethane) buffer to deionized water and then adding ultrapure $\mathrm{HNO}_{3}$ to bring the solution to the desired $\mathrm{pH}$ value. Alkaline solutions $(\mathrm{pH}=11)$ were prepared by adding $\mathrm{LiCl}$ and $\mathrm{LiOH}$ to deionized water. In Table 2.1, the calculated $\mathrm{pH}$ at $90^{\circ} \mathrm{C}$ is also shown. This $\mathrm{pH}$ value was calculated with the EQ3NR computer code (Wolery 1992a). As one can see from Table 2.1, the in-situ $\mathrm{pH}$ of the experiment can change by as much as $1.5 \mathrm{pH}$ units over the temperature interval of $23^{\circ}$ to $90^{\circ} \mathrm{C}$; about half of this change is due to the shift in the neutral $\mathrm{pH}$ of water (Table 2.1).

Table 2.1. Chemical Compositions Used in SPFT Experiments. Solution $\mathrm{pH}$ values at $90^{\circ} \mathrm{C}$ were calculated with EQ3NR Code V7.2b database (Wolery 1992b)

\begin{tabular}{||c|c|c||l||}
\cline { 2 - 4 } \multicolumn{1}{c|}{} & Target & Estimated & \multicolumn{1}{c||}{} \\
\hline \hline Solution \# & pH $\left(\mathbf{2 5}^{\circ} \mathbf{C}\right)$ & $\mathbf{p H ~}(\mathbf{9 0} \mathbf{C})$ & Composition \\
\hline 1 & 2.0 & 2.0 & $0.01 \mathrm{M} \mathrm{HNO}_{3}$ \\
\hline 2 & 7.0 & 5.5 & $0.01 \mathrm{M} \mathrm{THAM}+0.009 \mathrm{M} \mathrm{HNO}_{3}$ \\
\hline 3 & 8.0 & 6.5 & $0.01 \mathrm{M} \mathrm{THAM}+0.006 \mathrm{M} \mathrm{HNO}_{3}$ \\
\hline 4 & 9.0 & 7.3 & $0.01 \mathrm{M} \mathrm{THAM}+0.003 \mathrm{M} \mathrm{HNO}_{3}$ \\
\hline 5 & 10.0 & 9.2 & $0.01 \mathrm{M} \mathrm{THAM}+0.001 \mathrm{M} \mathrm{LiOH}$ \\
\hline 6 & 11.0 & 10.1 & $0.01 \mathrm{M} \mathrm{LiCl}+0.011 \mathrm{M} \mathrm{LiOH}$ \\
\hline Water & 7 & 6.2 & Neutral pH \\
\hline
\end{tabular}


Aliquots of effluent solution, whether from the titanium or the Teflon SPFT apparatus, were routinely checked to assure that $\mathrm{pH}$ control was maintained during the experiment. Other aliquots were reserved for radiochemical assay with counting techniques. Gamma energy analyses were used to analyze for ${ }^{239} \mathrm{Pu},{ }^{238} \mathrm{Pu},{ }^{240} \mathrm{Pu},{ }^{241} \mathrm{Pu}$, and ${ }^{241} \mathrm{Am}$ in an aliquot of the effluent solution. The remainder of the effluent was acidified $(\mathrm{pH}<2)$ with high-purity nitric acid and analyzed for $\mathrm{Ce}, \mathrm{Gd}, \mathrm{Hf}, \mathrm{Mo},{ }^{239} \mathrm{Pu}, \mathrm{Ti}$, and mass-238 species concentrations with inductively coupled plasma-mass spectroscopy. "Mass-238" species include ${ }^{238} \mathrm{U}$ and ${ }^{238} \mathrm{Pu}$, which we assumed constituted the total of species of mass-238 (i.e., ${ }^{238} \mathrm{U}+$ ${ }^{238} \mathrm{Pu}=$ mass-238). Concentrations of ${ }^{238} \mathrm{U}$ were determined by subtracting the concentration of ${ }^{238} \mathrm{Pu}$ determined by counting methods from the mass-238 species. Concentrations of Ti in effluent solutions from the titanium reactor experiments were not determined, for obvious reasons. Concentrations of Al and $\mathrm{Ca}$ in with the solutions from the tests with ${ }^{239} \mathrm{Pu}$-bearing ceramics were determined with optical emission spectroscopy methods. This technique was not used for solutions from tests with ${ }^{238} \mathrm{Pu}$ specimens because the optical emission spectroscopy was not set-up to handle solutions having high activity.

Typically, three blank solutions were drawn before the specimen was added to the reactor. The blank solutions were analyzed for background concentrations of elements of interest and, together with analyses of starting solution aliquots, assured us that contamination from previous experiments was not a factor. Blanks, which were set up identically to the other reaction cells, but without a test specimen, were used to monitor the Mo in the starting $\mathrm{pH}$-buffered leach solutions. Analyses of the solutions from the blanks showed that the concentrations of Mo remained relatively low, but increased as water evaporated from the reservoir under flowing nitrogen. Some evaporation of the input solution was expected, especially as the reservoir reached empty. In most cases, reservoir bottles were exchanged before significant evaporation occurred. Any slight rise in background Mo concentrations was recorded. These concentrations dropped to near detection level ( $\sim 0.10 \mathrm{ppb})$ after the leachant was changed. The concentration of Mo from the blank was subtracted from the Mo concentration in the effluent solutions.

\subsection{Dissolution Rate and Error Calculations}

We calculate dissolution rates from the concentrations of elements in effluent solutions. The duration of any experiment continued until the concentrations of elements in solution attained steady-state (i.e., constant with respect to time) values. These rates are normalized to the amount of the element present in the ceramic and calculated with the formula:

$$
r_{i, j}=\frac{\left(C_{i, j}-\bar{C}_{i, b}\right) q_{j}}{f_{i} S_{j}}
$$

where

$r_{i, j}=$ the normalized release rate $\left[\mathrm{g} /\left(\mathrm{m}^{2} \cdot \mathrm{d}\right)\right]$ based on element $i$ at the $j^{\text {th }}$ sampling

$C_{i, j}=$ the concentration $\left(\mathrm{g} \cdot \mathrm{m}^{-3}\right)$ of the element, $I$, in the effluent at the $j^{\text {th }}$ sampling

$\bar{C}_{i, b}=$ the average background concentration $\left(\mathrm{g} \cdot \mathrm{m}^{-3}\right)$ of the element of interest

$q_{j}=$ the flowrate $\left(\mathrm{m}^{3} \cdot \mathrm{d}^{-1}\right)$ at the $j^{\text {th }}$ sampling

$\mathrm{f}_{i}=$ the mass fraction of the element in ceramic (dimensionless)

$S_{j}=$ the average surface area $\left(\mathrm{m}^{2}\right)$ of the specimen over the time period $j-1$ to $j$. 
The lower limit of quantification of any element is defined here as the lowest concentration calibration standard that can be determined reproducibly $( \pm 10 \%)$ during an analytical run. In cases where the concentration of the analyte is below the lower limit of quantification (LOQ), the background concentration of the ele ment is set at the value of the LOQ, even though the concentration of the element could be much lower. For most elements ( $\mathrm{Gd}, \mathrm{Pu}, \mathrm{U}, \mathrm{Mo}$, and $\mathrm{Hf}$ ), the LOQ is $\sim 0.10 \mathrm{ppb}$. Higher detection thresholds were determined for $\mathrm{Ti}$ (up to $5 \mathrm{ppb}$ ) and $\mathrm{Ca}$ (up to $10 \mathrm{ppb}$ ). Only in the case of $\mathrm{Ca}$ were background concentrations consistently detected; these ranged as high as $80 \mathrm{ppb}$. Flowrates are determined from the mass of solution collected in each effluent collection vessel upon sampling. The value of $f_{i}$ is calculated from the chemical composition of the ceramic. Surface areas of powdered specimens were determined for the non-radioactive samples with the $\mathrm{Kr}$ Brunauer, Emmett, and Teller (B.E.T.) (Brunauer et al. 1938) methods for the $<150$ to $>75 \mu \mathrm{m}$ and $<75$ to $>25 \mu \mathrm{m}$ size fractions from which surface areas of 0.057 and $0.128 \mathrm{~m}^{2} \mathrm{~g}^{-1}$, respectively, were calculated. Because we were unable to measure them, we assumed that the size ranges for the non-radioactive samples are representative of powders of the ${ }^{238} \mathrm{Pu}$ - and ${ }^{239} \mathrm{Pu}$-bearing specimens. Changes in the specimen surface area during the experiment were estimated as described by McGrail et al. (1997). In all cases, such surface-area corrections were negligible. In many of the experiments, we used monoliths rather than powders. Monoliths rested on a raised, grated Teflon stage that allowed the maximum surface area to be exposed. The use of monoliths allowed us to explore a greater range of flowrate to surface-area ratios than would have been practical with powders. Monolith surface areas were calculated by measuring the diameter and height of the specimen and assuming that the monoliths are right circular cylinders.

Experimental uncertainties for the SPFT were determined with a propagation-of-errors analysis. The relative errors (s) in the apparent rates are given by the formula:

$$
\hat{\sigma}_{r}=\sqrt{\frac{\left(\hat{\sigma}_{c} C_{i, j}\right)^{2}+\left(\hat{\sigma}_{b} \bar{C}_{i, b}\right)^{2}}{\left(C_{i, j}-\bar{C}_{i, b}\right)^{2}}+\hat{\sigma}_{q}^{2}+\hat{\sigma}_{f_{i}}^{2}+\hat{\sigma}_{S}^{2}}
$$

The uncertainties in $C_{i}, \bar{C}_{i, b}, q, \mathrm{f}_{i}$, and $S$ are $10 \%, 10 \%, 10 \%, 5 \%$, and $15 \%$, respectively. The resulting uncertainties in the experimentally determined rates are $20 \%$ to $40 \%$, depending mainly on the difference in concentration between the effluent and influent solutions. When the difference is small, the calculated uncertainties are large. Typically, experimental uncertainties of $20 \%$ were calculated.

\subsection{Chemical Compositions of the Titanate Ceramics}

Previous reports have described in detail the chemical compositions of the titanate ceramics, so only a cursory discussion will be presented in this report. Multi-phase ceramic waste forms, including the related Synroc composition, are chiefly based on two titanium-bearing minerals: pyrochlore (betafite family) and zirconolite. Betafite isostructures are represented by the formula $\mathrm{A}_{0-1} \mathrm{~B}_{1-2} \mathrm{Ti}_{2} \mathrm{O}_{7}\left(\mathrm{~A}=\mathrm{Ca}^{2+}\right.$ and $\mathrm{Gd}^{3+}$ and $\mathrm{B}=\mathrm{Gd}^{3+}, \mathrm{Ce}^{4+}, \mathrm{Hf}^{4+}, \mathrm{U}^{4+}$, and $\mathrm{Pu}^{4+}$ ) with an anion-deficient, fluorite structure. Zirconolite can be represented by the formula $\mathrm{ABTi}_{2} \mathrm{O}_{7}$ with $\mathrm{A}=\mathrm{Ca}^{2+}$ and $\mathrm{B}=\mathrm{Hf}^{4+}, \mathrm{U}^{4+}$, and $\mathrm{Pu}^{4+}$. In addition to pyrochlore and zirconolite, minor phases include brannerite and $\mathrm{TiO}_{2}$ polymorphs. The brannerite isostructure is represented by the formula $\left(\mathrm{A}^{4+}\right) \mathrm{Ti}_{2} \mathrm{O}_{6}$, with $\mathrm{Hf}^{4+}, \mathrm{U}^{4+}$, and $\mathrm{Pu}^{4+}$ the likely dominant cations. Ebbinghaus et al. (1999) have a complete discussion of the likely substitutions for these phases. 
In this report, we refer to "pure phase" ceramics, including pyrochlore, zirconolite, and brannerite. Clearly, the intended chemical makeup of these specimens is that of a single phase, although some amount of $\mathrm{TiO}_{2}$ polymorphs also is present. The main focus of this investigation is on the multi-phase material discussed above, which is denoted as "baseline." In our investigation, the primary "baseline" ceramic is that of pyrochlore baseline, which is a multi-phase ceramic dominated volumetrically by pyrochlore-group minerals.

Both non-radioactive and ${ }^{239} \mathrm{Pu}$ - and ${ }^{238} \mathrm{Pu}$-bearing pure phase and baseline ceramics are represented in this study. In the non-radioactive specimens, cerium $\left(\mathrm{as}_{\mathrm{CeO}}\right)$ was used as a surrogate for $\mathrm{U}$ and $\mathrm{Pu}$. The ${ }^{239} \mathrm{Pu}$ - and ${ }^{238} \mathrm{Pu}$-bearing specimens also contain a small amount of $\mathrm{Al}^{3+}$, which is not present in the non-radioactive samples. In addition, all ceramics contain small concentrations $(\leq 0.1$ mass $\%)$ of $\mathrm{Mo}^{6+}$ that was included as a tracer for matrix dissolution in the SPFT tests.

Chemical compositions of the various "pure phase" and "baseline" ceramics are listed in

Table 2.2. A number of different bulk chemical compositions of the pyrochlore, pyrochlore-rich baseline, and zirconolite specimens are listed, as indicated. We also included the chemical compositions of two gadolinium end-member pyrochlore specimens (Gd-Py and ZR-00) that we used to construct some of the figures on the following pages. These two specimens are being studied in a separate program under the direction of Dr. W.J. Weber. Note that we have summarized bulk chemical analyses of the titanate ceramics that we presented in earlier reports. The analyses were performed using electron microprobe analysis (EMPA) and, generally, are close to the target compositions. Previous reports also demonstrated that, at least for the non-radioactive ceramics, there is no detectable chemical zoning of elements within the pyrochlore and zirconolite phases. In addition, no evidence of disequilibrium or phase separation was apparent with this technique. Significantly, the distribution of $\mathrm{Mo}^{6+}$ appears to be homogeneous throughout the ceramic phases. 
Table 2.2. Chemical Compositions (in mass\%) of Titanate Ceramics

\begin{tabular}{|c|c|c|c|c|c|c|c|c|}
\hline \multirow[b]{2}{*}{ Oxide } & \multicolumn{3}{|c|}{ Pyrochlore-Rich Baseline } & \multicolumn{3}{|c|}{ Pyrochlore } & \multicolumn{2}{|c|}{ Zirconolite } \\
\hline & $\begin{array}{l}\text { BSL-3 } \\
\text { Target } \\
\text { (wt.\%) }\end{array}$ & $\begin{array}{l}\text { BSL-3 } \\
\text { EMPA } \\
\text { (wt.\%) }\end{array}$ & $\begin{array}{r}\text { Pu-239 } \\
\text { Target } \\
\text { (wt.\%) }\end{array}$ & $\begin{array}{l}\text { PY-12 } \\
\text { Target } \\
\text { (wt.\%) }\end{array}$ & $\begin{array}{l}\text { PY-21 } \\
\text { EMPA } \\
\text { (wt. } \%)\end{array}$ & $\begin{array}{l}\mathrm{Pu}-239 \\
\text { Target } \\
\text { (wt.\%) }\end{array}$ & $\begin{array}{c}\text { ZR-6 } \\
\text { Target } \\
\text { (wt.\%) }\end{array}$ & $\begin{array}{c}\text { ZR-6 } \\
\text { EMPA } \\
\text { (wt.\%) }\end{array}$ \\
\hline $\mathrm{Al}_{2} \mathrm{O}_{3}$ & 0.00 & 0.00 & 0.00 & 0.00 & 0.00 & 0.00 & 1.74 & 2.52 \\
\hline $\mathrm{CaO}$ & 11.47 & 10.71 & 9.94 & 8.23 & 7.58 & 12.07 & 10.20 & 8.73 \\
\hline $\mathrm{Gd}_{2} \mathrm{O}_{3}$ & 9.16 & 9.23 & 7.94 & 13.31 & 13.06 & 7.64 & 2.06 & 1.96 \\
\hline $\mathrm{HfO}_{2}$ & 11.12 & 11.76 & 9.63 & 3.10 & 3.92 & 10.88 & 43.06 & 45.02 \\
\hline $\mathrm{MoO}_{3}$ & 0.08 & 0.08 & 0.08 & 0.08 & 0.08 & 0.08 & 0.08 & 0.00 \\
\hline $\mathrm{PuO}_{2}$ & 0.00 & 0.00 & 11.88 & 0.00 & 0.00 & 12.35 & 7.39 & 0.00 \\
\hline $\mathrm{TiO}_{2}$ & 41.33 & 40.26 & 36.82 & 39.89 & 39.34 & 36.15 & 33.60 & 35.55 \\
\hline $\mathrm{UO}_{2}$ & 0.00 & 0.00 & 23.67 & 0.00 & 0.00 & 20.82 & 1.84 & 0.00 \\
\hline $\mathrm{CeO}_{2}$ & 26.84 & 27.85 & 0.00 & 35.38 & 35.80 & 0.00 & 0.00 & 5.79 \\
\hline TOTAL & 100.00 & 99.89 & 99.96 & 99.99 & 99.78 & 99.99 & 99.97 & 99.57 \\
\hline
\end{tabular}

\begin{tabular}{|c|c|c|c|c|c|c|c|c|}
\hline \multirow[b]{2}{*}{ Oxide } & \multicolumn{2}{|c|}{ Pyrochlore-Rich Baseline } & \multicolumn{4}{|c|}{ Pyrochlore } & \multirow{2}{*}{\begin{tabular}{c||} 
Zirconolite \\
HZ-6X, ZZ \\
Target \\
(wt.\%)
\end{tabular}} & \multirow{2}{*}{$\begin{array}{c}\text { Brannerite } \\
\text { HCBLx } \\
\text { Target } \\
\text { (wt.\%) }\end{array}$} \\
\hline & $\begin{array}{l}\text { Hbas-6 } \\
\text { Target } \\
\text { (wt.\%) }\end{array}$ & $\begin{array}{c}\text { BSL-238 } \\
\text { Target } \\
\text { (wt.\%) }\end{array}$ & $\begin{array}{l}\text { PY-17 } \\
\text { Target } \\
(\text { wt. } \%)\end{array}$ & $\begin{array}{c}{ }^{(1)} \text { Gd-PY } \\
\text { EMPA } \\
(w t . \%)\end{array}$ & $\begin{array}{c}{ }^{(2)} \text { ZR-00 } \\
\text { EMPA } \\
(w t . \%)\end{array}$ & $\begin{array}{l}\text { PY-238 } \\
\text { Target } \\
\text { (wt.\%) }\end{array}$ & & \\
\hline $\mathrm{Al}_{2} \mathrm{O}_{3}$ & 0.00 & $\begin{array}{c}0.00 \\
\end{array}$ & 0.00 & 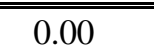 & 0.00 & 0.00 & 2.52 & 0.00 \\
\hline $\mathrm{CaO}$ & 11.47 & 9.91 & 8.23 & 0.00 & 0.00 & 12.06 & 8.73 & 0.00 \\
\hline $\mathrm{Gd}_{2} \mathrm{O}_{3}$ & 9.16 & 7.95 & 13.31 & 70.71 & 70.05 & 7.65 & 1.96 & 0.00 \\
\hline $\mathrm{HfO}_{2}$ & 11.12 & 9.61 & 3.10 & 0.00 & 0.00 & 10.88 & 45.02 & 0.00 \\
\hline $\mathrm{MoO}_{3}$ & 0.08 & 0.11 & 0.08 & 0.00 & 0.00 & 0.08 & 0.00 & 0.00 \\
\hline $\mathrm{PuO}_{2}$ & 0.00 & 11.84 & 0.00 & 0.00 & 0.00 & 12.31 & 0.00 & 0.00 \\
\hline $\mathrm{TiO}_{2}$ & 41.33 & 36.70 & 39.89 & 29.02 & 29.19 & 36.17 & 35.55 & 48.10 \\
\hline $\mathrm{UO}_{2}$ & 0.00 & 23.88 & 0.00 & 0.00 & 0.00 & 20.82 & 0.00 & 0.00 \\
\hline $\mathrm{CeO}_{2}$ & 26.84 & 0.00 & 35.38 & 0.00 & 0.00 & 0.00 & 5.79 & 51.80 \\
\hline TOTAL & 100.00 & 100.00 & 99.99 & 99.73 & 99.24 & 99.97 & 99.57 & 99.90 \\
\hline
\end{tabular}

Notes: "Target" represents the desired bulk chemical compositions whereas "EMPA" denotes the composition of the sample measured by Electron Micro-Probe Analysis. (1) and (2) are gadolinium pyrochlore samples from another related program. The compositions are displayed because the data in Figure 3.2 include results from experiments with Gd-PY and ZR-00. 


\subsection{Results}

\subsection{Dependence of Reaction Rate on Flowrate}

Although the experiments with materials containing Pu are included on the following set of diagrams, our primary purpose in this section is to elucidate the behavior of the specimens over a wide range of flowrates and surface areas. Fewer tests were performed with the Pu-bearing specimens, so the majority of the data in this section are from the non-radioactive powder and monolithic specimens.

Experimental conditions, including effluent $\mathrm{pH}$, average flowrate, mass of the specimen, and average net (i.e., background corrected) concentration of the elements are listed in Tables A.1 through A.11 (see Appendix A). Dissolution-rate data, including experimental uncertainties, are listed in Tables A.12 through A.22 (see Appendix A). Although the number of data tables is large, the data are grouped in such a way as to facilitate discussion.

Most of the experiments were performed with leachants at $\mathrm{pH}=2$ and a temperature of $90^{\circ} \mathrm{C}$. The tests run with ${ }^{238} \mathrm{Pu}$-bearing specimens were performed at $85^{\circ} \mathrm{C}$. At $\mathrm{pH}=2$, concentrations of $\mathrm{U}, \mathrm{Pu}, \mathrm{Ce}, \mathrm{Ca}$, and Gd are likely above their respective lower limit of quantification (LOQ). The release of $\mathrm{U}, \mathrm{Pu}, \mathrm{Ce}$, $\mathrm{Ca}$, and $\mathrm{Gd}$ appear to be congruent in most of the experiments. Accordingly, we have multiple rate data to support our conclusions in this report. Concentrations of $\mathrm{Hf}$ are low in all effluent solutions from all tests, possibly reflecting solubility limits (Rai et al. 2001). Concentrations of dissolved Ti are constant over the flowrate and surface-area regime, which we interpret to indicate release and re-precipitation on the surface as an amorphous $\mathrm{TiO}_{2}$ polymorph (see below). Molybdenum has been shown to sorb on the surface of precipitated $\mathrm{TiO}_{2}$ at low $\mathrm{pH}$ values (Saripalli et al. 2001), so it is not surprising that Mo concentrations are very low in most $\mathrm{pH} 2$ experiments.

Release of Gd to $\mathrm{pH}=2$ solution was used to monitor the dissolution rate of each specimen. Gadolinium is particularly useful because it easy to detect to very low concentrations in solution. In some cases, either $\mathrm{U}$ or Ce was used to determine dissolution rates for specimens that lacked sufficient Gd (e.g., Cebrannerite). The wide range of concentrations that could be solidly determined allowed us to vary the flowrate, $q$, to surface area, $S$, ratio (units of $\mathrm{m} \mathrm{s}^{-1}$ ) over a broad set of values. Figure 3.1 illustrates the dependence of the rate on $q / S$ for the zirconolite specimens. Note that both powdered and monolithic specimens are represented on this diagram. At small values of $q / S$, solutions are relatively concentrated, and the rates are slow. Progressively higher values of $q / S$ yield rates that increase at a near constant slope. At some value of $q / S$, the rates become independent of solution composition, and a constant dissolution rate is obtained. The "dissolution plateau" illustrated by the data points and the non-linear curve regressed through them indicates the forward rate of dissolution. In the case of zirconolite, the forward rate is $\sim 1.5 \cdot 10^{-3} \mathrm{~g} /\left(\mathrm{m}^{2} \cdot \mathrm{d}\right)\left(\log \left\{\operatorname{rate}\left[\mathrm{g} /\left(\mathrm{m}^{2} \cdot \mathrm{d}\right)\right]\right\}=-2.81\right)$. Also shown on this diagram are the data representing the brannerite dissolution rates. Because the range of $q / S$ values was limited, the rate determined from these tests was the minimum forward rate of brannerite dissolution. The brannerite dissolution rate of $6.6 \cdot 10^{-3} \mathrm{~g} /\left(\mathrm{m}^{2} \cdot \mathrm{d}\right)$ most likely represents the forward rate of reaction. If true, brannerite dissolves approximately a factor of 4 faster than zirconolite, in keeping with previous investigations (Lumpkin, Leung, and Colella 2000). 
The behavior of the pyrochlore-rich baseline and "pure phase" pyrochlore in test solutions is similar. By using a variety of powdered specimen masses or monoliths and by manipulating flowrates, we were able to obtain a 1000 -fold variation in $q / S$ and the response in rate to this ratio. Dissolution rates vary by five orders of magnitude $\left[10^{-2}\right.$ to $\left.10^{-7} \mathrm{~g} /\left(\mathrm{m}^{2} \cdot \mathrm{d}\right)\right]$ over the conditions of the experiments (Figure 3.2). As $q / S$ was increased, the dissolution rates approached constant values. For ease of discussion, we divided the

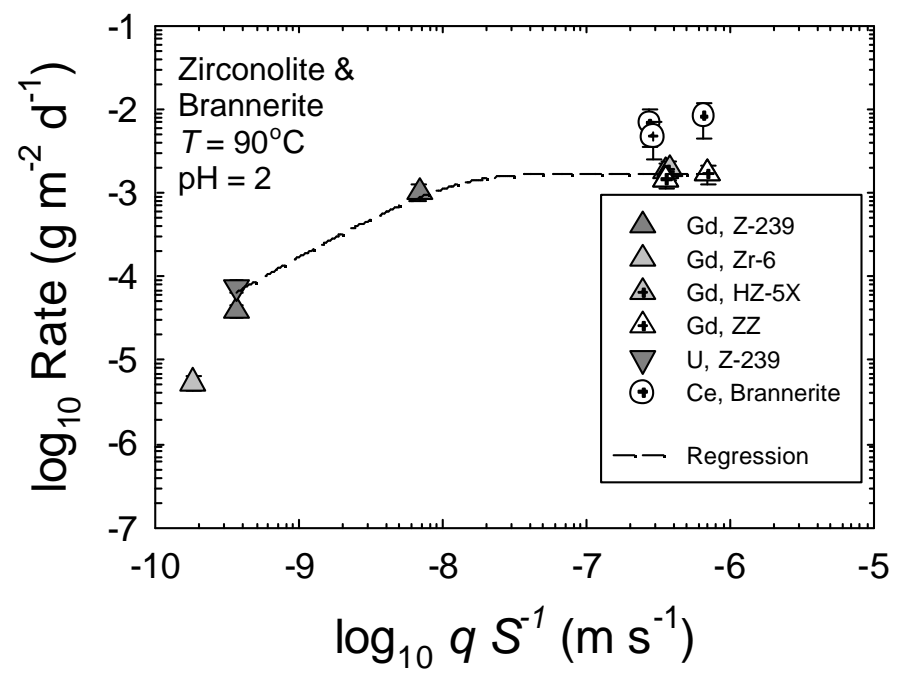

Figure 3.1. Plot of the Dissolution Rate Versus the Flowrate to Surface Area (q/S) Ratio for Zirconolite Powders and Monoliths at $90^{\circ} \mathrm{C}, \mathbf{p H}=2$. $\mathrm{Zr}-6, \mathrm{HZ}-6 \mathrm{X}$, and $\mathrm{ZZ}$ refer to specimens from individual batches of material; there is no difference in bulk chemistry between them. The non-linear regression indicates a $\log$ [forward rate $\left(\mathrm{g} \mathrm{m}^{-2} \mathrm{~d}^{-1}\right)$ ] of $\mathbf{- 2 . 8 1}$.

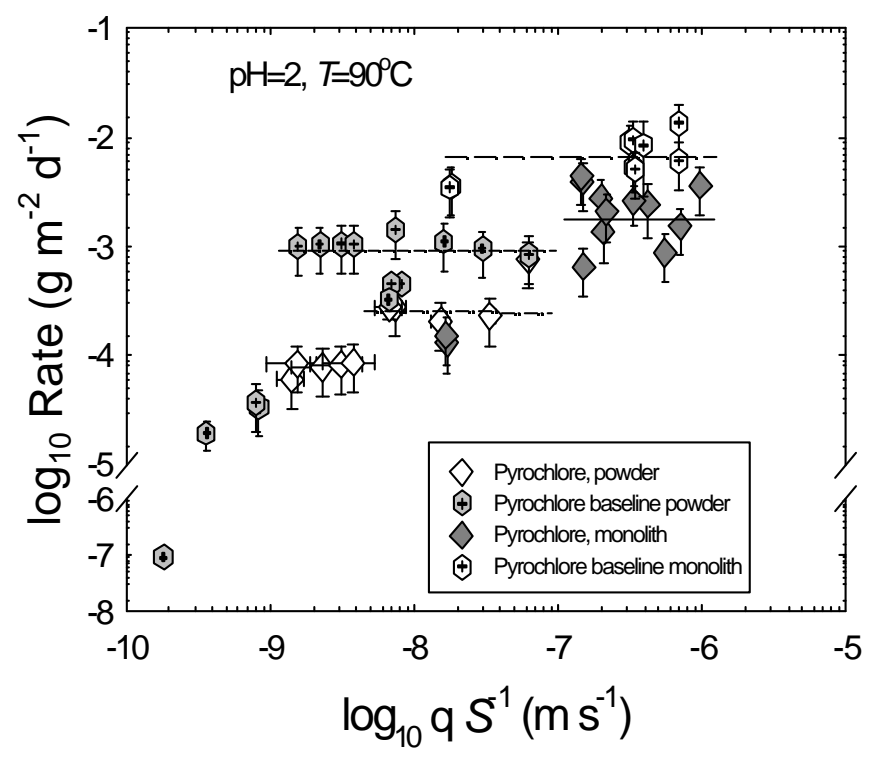

Figure 3.2. Plot Log Dissolution Rate Versus Log q/S for Data from Experiments with PyrochloreRich Baseline and Pure Phase Pyrochlore Specimens. All data were collected at $90^{\circ} \mathrm{C}$ and $\mathbf{p H}=2$ solutions. The horizontal lines mark the apparent forward rate of reaction. 
samples into four categories: 1) "pure phase" pyrochlore powders, 2) "pure phase" pyrochlore monoliths, 3) pyrochlore-rich baseline powders, and 4) pyrochlore-rich baseline monoliths. Of these groups of data, perhaps those representing the reaction rate of the pyrochlore baseline powders are easiest to understand. Dissolution rates change sharply below a $\log \left[q / S\left(\mathrm{~m} \mathrm{~s}^{-1}\right)\right]$ value of -9 , but then reach a constant rate $\left(\log \left\{\operatorname{rate}\left[\mathrm{g} /\left(\mathrm{m}^{2} \cdot \mathrm{d}\right)\right]\right\}=-3.0\right)$. Note that the ${ }^{239} \mathrm{Pu}-$ and ${ }^{238} \mathrm{Pu}$-bearing powders are included in this set and seamlessly match the rates of the non-radioactive powders. A medium-weight dashed line highlights the probable forward rate of reaction for these materials, but the line has no statistical significance (it is only provided as a guide to the eye). Results from experiments with pyrochlore-rich baseline monoliths indicate a forward rate of nearly a factor of 10 higher than that from powdered specimens of the same composition. Although there are no data for very small values of $q / S$, the data indicate constant rates over a large interval at high $q / S$ values. In a similar fashion, forward rates of dissolution determined for powdered pure phase pyrochlore specimens attain constant values $\left(\log \left\{\operatorname{rate}\left[\mathrm{g} /\left(\mathrm{m}^{2} \cdot \mathrm{d}\right)\right]\right\}=-2.7\right)$ above $\log \left[q / S\left(\mathrm{~m} \mathrm{~s}^{-1}\right)\right]$ of -8.5 . For values of $q / S$ lower than this, the rates sharply decline, as they did for data representing pyrochlore-rich baseline ceramics. We used these data to design the experiments in which the titanium reactors were used. We chose $q / S$ values that assured that the ${ }^{238} \mathrm{Pu}$-bearing specimens were dissolving at the forward rate of reaction. In fact, rate data from the experiments with ${ }^{238} \mathrm{Pu}-$ and ${ }^{239} \mathrm{Pu}-$ bearing powders plot at the forward rate value (although their symbols are not distinguished from those representing non-radioactive specimens), in keeping with the very dilute solutions used in these experiments. In parallel with the pyrochlore-rich baseline data, the reaction rates of pure-phase pyrochlore monoliths reach a constant value that is nearly a factor of 10 higher than the reaction rates for the pyrochlore powders. Although there is some scatter, the data appear to cluster around the value of $\log \left\{\operatorname{rate}\left[\mathrm{g} /\left(\mathrm{m}^{2} \cdot \mathrm{d}\right)\right]\right\}=-2.7$. Some of the scatter can be attributed to plotting the data for Gd-pyrochlore samples from the EMSP project because of the difficulties in estimating the surface areas of the irregularly shaped monoliths. Nevertheless, the data are consistent with the forward dissolution rates of the monolithic specimens.

\subsection{Dissolution Rates of ${ }^{238} \mathrm{Pu}-$ Bearing Ceramics}

Dissolution rates of the ${ }^{238} \mathrm{Pu}$-bearing ceramics determined with the titanium SPFT apparatus are tabulated in Tables A18 and A21. The rates of three different specimens were determined: 1) a pyrochlore-rich baseline specimen that had been annealed immediately before testing began, 2) an un-annealed pyrochlorerich baseline specimen that was created in October, 1999, and 3) an annealed pure phase pyrochlore specimen.

Concentrations of Gd over the duration of the experiments are plotted in Figure 3.3. The data indicate that $\mathrm{Gd}$ release has reached steady-state conditions, so dissolution rates based on this element should

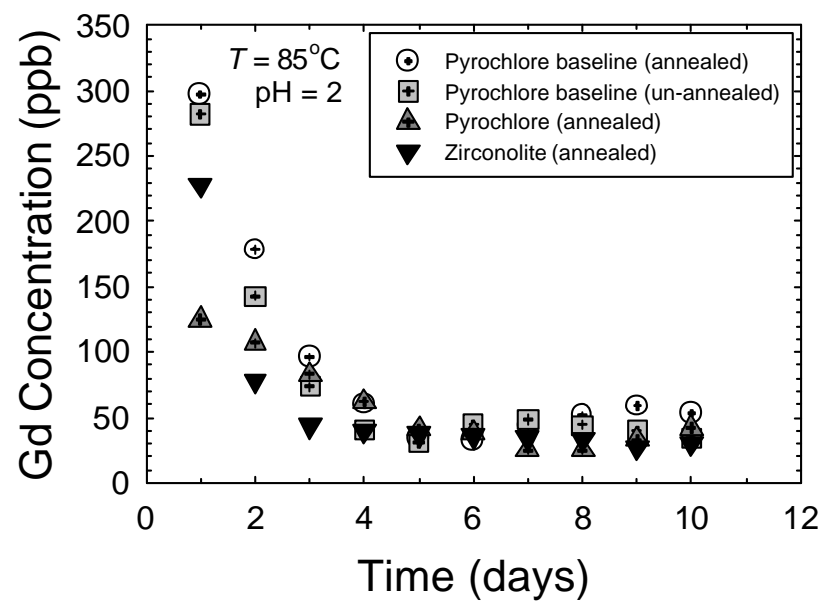

Figure 3.3. Plot of the Concentration of Gd Versus Time for the Three Experiments Containing ${ }^{238} \mathrm{Pu}$ and the ${ }^{239} \mathrm{Pu}$ Zirconolite Specimens. 
provide forward rate results. The data for release of Pu and $\mathrm{U}$ (Figure 3.4) are less reliable than those for the release of $\mathrm{Gd}$. The concentrations of the elements released from the pyrochlore and zirconolite specimens appear to attain steady-state behavior, but attainment of steady-state of Pu release from the two pyrochlore baseline specimens is ambiguous. For the annealed specimen, the Pu release rises to a steadystate value, which runs counter to intuition (compare with the Gd release plot, Figure 3.3). Further, release of $\mathrm{Pu}$ from the un-annealed specimen does not appear to attain steady-state values after rising to a maximum. Interpretation of the release of $U$ from the specimens is also somewhat ambiguous, and steady-state values can only be estimated. Note also that release of $U$ from the zirconolite sample is far faster than from the other specimens, and concentrations do not come to any true steady-state value. In summary, the release of Gd to solution is the most reliable monitor of the dissolution process, and rates obtained from $\mathrm{U}$ and $\mathrm{Pu}$ release must be compared to the Gd data.
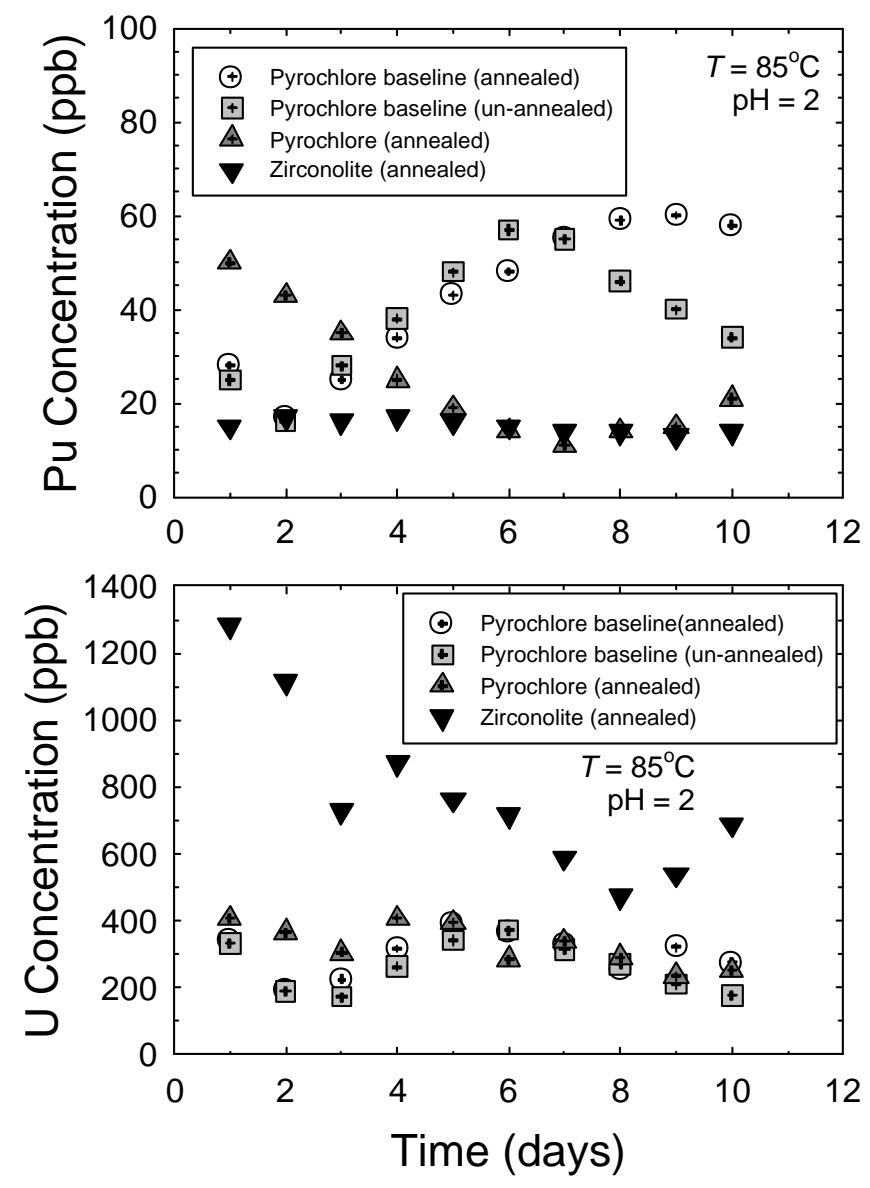

Figure 3.4. Plot of the Concentration of $U$ and Pu Versus Time for the Three Experiments Containing ${ }^{238} \mathrm{Pu}$ and the ${ }^{239} \mathrm{Pu}$ Zirconolite

\subsection{Titanium Saturation}

Although the concentrations of $\mathrm{Gd}, \mathrm{Ce}, \mathrm{U}$, and Pu change as a function of $q / S$, the concentration of Ti appears to be constant at $90^{\circ} \mathrm{C}$ and $\mathrm{pH}=2$. Shown in Figure 3.5 are plots of the concentration of dissolved $\mathrm{Ti}$ in the leachates from pyrochlore, pyrochlore-rich baseline, and zirconolite. The dashed line in the figure represents the solubility of $\mathrm{TiO}_{2}$ at $100^{\circ} \mathrm{C}$ from the work of Knauss et al. (2001). 
Unfortunately, there are insufficient data to allow us to accurately extrapolate the $\log \mathrm{K}$ values to $90^{\circ} \mathrm{C}$, but the insensitivity with respect to temperature suggests that the value at $100^{\circ} \mathrm{C}$ is not too different than the value at $90^{\circ} \mathrm{C}$ (Knauss et al. 2001). The observed concentration of Ti in the effluent from our tests is very close to the $100^{\circ} \mathrm{C}$ solubility value. Therefore, it is likely that the solutions are saturated with respect to $\mathrm{TiO}_{2}$, probably anatase (Begg et al. 2000).

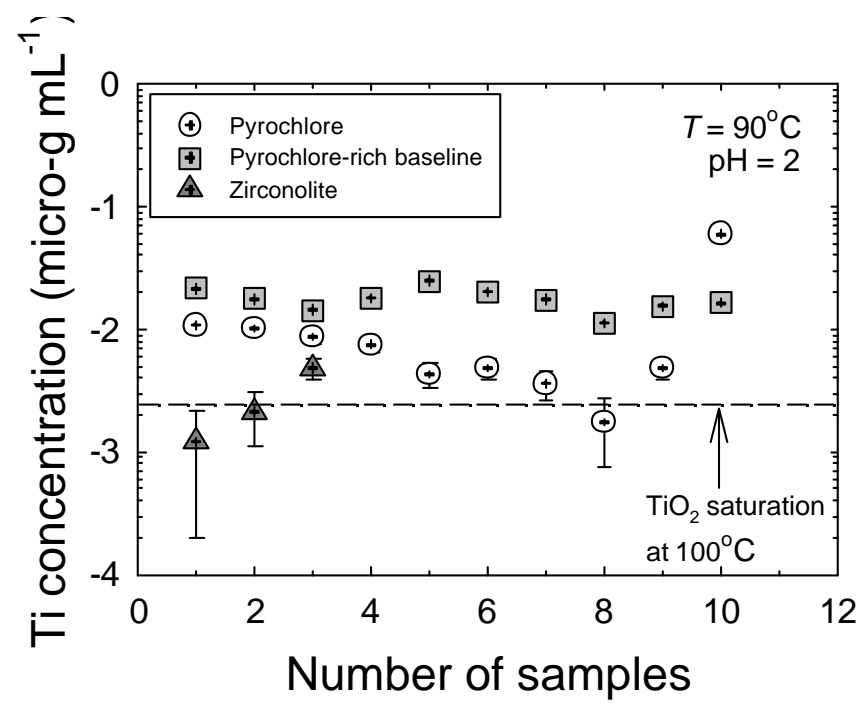

Figure 3.5. Plot of Ti Concentration of Effluent Samples from Dissolution Experiments on Pyrochlore, Pyrochlore-Rich Baseline, and Zirconolite at $90^{\circ} \mathrm{C}$ and $\mathrm{pH}=2$. The $100^{\circ} \mathrm{C}$ $\mathrm{TiO}_{2}$ saturation concentration is displayed as the dashed line (Knauss et al. 2001). 


\subsection{Discussion}

\subsection{Influence of Radiation Damage on Titanate Dissolution Rates}

Of primary concern to the long-term behavior of the immobilized $\mathrm{Pu}$ form is the effect of radiationinduced damage on the physical and chemical properties of the material. This effect has clear implications for the disposal of an immobilized Pu product in a geologic repository. In our earlier work, we found that ${ }^{238} \mathrm{Pu}$-bearing ceramics released elements to solution from 80 to 1000 times faster than their ${ }^{239} \mathrm{Pu}$-bearing analogs (Strachan et al. 2001a). Because the ${ }^{238} \mathrm{Pu}$-bearing sample had accumulated a large amount of radiation-induced damage before testing actually began, we were unable to come to a conclusion as to the exact cause for the high dissolution rates. There were at least two possible explanations: radiation induced damage or radiolysis of the leachant.

As mentioned in Section 2.2 (Methods and Materials), we were concerned about the low number of times the volume of leachant in the reaction vessel was exchanged. At the low number of volume exchanges, there was opportunity for radiolysis products to affect the dissolution rate of the ceramic material. In part, this effect would be diminished if the volume of the SPFT vessel were reduced. If the rate were lower relative to the rate determined with the larger vessels, we would know that radiolysis products were likely affecting the results. Second, despite the presence of a platinum sleeve in the Teflon vessel, we observed unusually high concentrations of fluoride in the leachates. These ranged as high as $100 \mathrm{ppm}$. Since the presence of fluoride ion suggests the presence of hydrofluoric acid and its concomitant corrosivity, there would always be questions surrounding the validity of the results from the ${ }^{238} \mathrm{Pu}$-bearing specimens when tested in a Teflon apparatus. These two potential effects alone were sufficient to cause us to change the design of the SPFT test apparatus to one constructed of Ti.

Having addressed the experimental apparatus questions, we addressed the question of radiation-induced effects by resintering a specimen before testing. Recrystallizing a specimen by resintering and comparing its dissolution test results with one that was fully damaged allowed us to determine the effect of radiation damage on the behavior of the titanate form. Further, we performed identical SPFT tests with nonradioactive and ${ }^{239} \mathrm{Pu}$-bearing specimens so that we had additional results against which to compare the results from the ${ }^{238} \mathrm{Pu}$-bearing specimens. If we had observed high dissolution rates for the ${ }^{238} \mathrm{Pu}$-bearing specimen after it was tested in the newly designed apparatus and confirmed that the dissolution rates were high in comparison to the non-radioactive and ${ }^{239} \mathrm{Pu}$-bearing specimens, then we would have been able to attribute the behavior to radiation-induced damage effects.

However, results from this testing regimen clearly indicate that there is no difference in dissolution rates between the un-annealed and the annealed specimens. Release rates of $\mathrm{Gd}, \mathrm{Pu}$, and $\mathrm{U}$ are identical within experimental uncertainty between the resintered and fully damaged ${ }^{238} \mathrm{Pu}$-bearing pyrochlore-rich baseline ceramics. Furthermore, the results from the ${ }^{238} \mathrm{Pu}$ experiments compare well with those from experiments on non-radioactive and ${ }^{239} \mathrm{Pu}$-bearing ceramics. Therefore, we conclude that radiation-induced damage has no measurable effect on dissolution rates, even when comparing X-ray amorphous materials (fully damaged) with those that are crystalline (resintered). 


\subsection{Conclusions}

Experiments employing SPFT techniques have been used to address the dissolution behavior of an immobilized $\mathrm{Pu}$ form for the disposition of weapons-ready Pu. Specimens made from non-radioactive chemicals or chemicals containing $\mathrm{Pu}$ and $\mathrm{U}$ have been tested with solutions over a wide range of solution $\mathrm{pH}$ (2 to 12$)$ at $85^{\circ} \mathrm{C}$ to $90^{\circ} \mathrm{C}$. For the ${ }^{238} \mathrm{Pu}$-bearing specimens, a SPFT test apparatus constructed from titanium was used to reduce or eliminate materials effects on the test results. The ceramic materials tested included various chemical compositions of pyrochlore, pyrochlore-rich baseline, zirconolite, and brannerite. The results show that there is essentially no difference in the dissolution rates between nonradioactive, ${ }^{239} \mathrm{Pu}$-, and ${ }^{238} \mathrm{Pu}$-bearing ceramics when the ratio of flowrate to surface area $(q / S)$ is high. Brannerite appears to be the most reactive phase with a forward dissolution rate of $6 \cdot 10^{-3} \mathrm{~g} /\left(\mathrm{m}^{2} \cdot \mathrm{d}\right)$. Zirconolite, pyrochlore-rich "baseline," and pyrochlore ceramics have forward dissolution rates of $2 \cdot 10^{-3}$, $1 \cdot 10^{-3}$, and $2 \cdot 10^{-4} \mathrm{~g} /\left(\mathrm{m}^{2} \cdot \mathrm{d}\right)$, respectively. Some differences in rate of about a factor of 10 were found when comparing rates obtained from powdered and monolithic specimens. Much, or all, of this difference can be accounted for solely by uncertainties surrounding measurements of specimen surface area. Hence, the high dissolution rates we saw earlier (Strachan et al. 2001a) were a result of radiolysis effects on the leachant that caused enhanced dissolution. These results indicate that, for the titanate materials tested, there is little or no change in the dissolution rates of the immobilized Pu forms with increasing radiation damage.

Although there are some ambiguities in the $\mathrm{Pu}$ and $\mathrm{U}$ release data, there are some important conclusions that can be derived from the data. First, the dissolution rates, based on the Gd, U, and Pu releases, of the annealed and un-annealed pyrochlore-rich baseline materials are the same within experimental error (see Table A.21). Second, the reaction rates for all four specimens are at the forward rate of reaction (Section 3.1). These reaction rates were based on Gd release, and many were determined at the same $q / S$ value. Many of the values for the reaction rates are the same within experimental error. Third, the dissolution rates from the other ${ }^{238} \mathrm{Pu}$-bearing pure phase pyrochlore and pyrochlore baseline specimens agree well with the dissolution rates determined for non-radioactive or ${ }^{239} \mathrm{Pu}$-bearing specimens. However, the $\mathrm{U}$ release rates are significantly different from the $\mathrm{Gd}$ and $\mathrm{Pu}$ release rates. Further, the $\mathrm{Pu}$ release rates from the pyrochlore and the zirconolite are much lower than one would expect based on the $\mathrm{Gd}$ or $\mathrm{U}$ release rates. In total, however, these data give us confidence that the experiments are yielding consistent results, despite differences in SPFT apparatuses, experimental conditions, and Pu-loading. Therefore, there does not yet appear to be any credible evidence for radiation damage causing accelerated dissolution rates. Instead, it appears that the high dissolution rates seen in the SPFT and MCC-1 tests (Strachan et al. 2001a; Strachan et al. 2001b; Strachan et al. 2002) are the result of radiolysis effects.

The dissolution rates for the immobilized Pu form are very low. The forward dissolution rates determined in this study for the immobilized Pu form are at least an order of magnitude slower than most glass waste forms, even at $\mathrm{pH}=6$ where the glass dissolution rate is at a minimum (McGrail et al. 1997). Therefore, titanate ceramics appear to be a viable immobilization form for weapons-ready $\mathrm{Pu}$. 


\subsection{References}

Begg, BD, WJ Weber, R Devanathan, JP Icenhower, S Thevuthasen, BP McGrail. 2000. Ceram. Trans. 107: 553-560.

Brunauer, S, PH Emmet, E Teller. 1938. J. Am. Chem. Soc. 64: 2383.

Cochran, SG, WH Dunlop, TA Edmunds, LM MacLean, TH Gould. 1997. Fissile Materials Disposition Program Final Immobilization form Assessment and Recommendation, UCRL-ID-128705, Lawrence Livermore National Laboratory, Livermore, CA.

Ebbinghaus, BB, C Cicero-Herman, L Gray, HF Shaw. 1999. Plutonium Immobilization Project:

Baseline Formulation, UCRL-ID-133089, Lawrence Livermore National Laboratory, Livermore, CA.

Knauss, KG, MJ Dibley, WL Bourcier, HF Shaw. 2001. Appl. Geochem. 16(9-10): 1115-1128.

Lumpkin, GR, SHF Leung, M Colella. 2000. "Composition, Geochemical Alteration, and Alpha-Decay Damage Effects of Natural Brannerite". Scientific Basis for Nuclear Waste Management XXIII 608: 359365.

McGrail, BP, WL Ebert, AJ Bakel, DK Peeler. 1997. J. Nucl. Mat. 249: 175-189.

Mitamura, M, S Matsumoto, MWA Stewart. 1994. J. Am. Ceram. Soc. 77(9): 2255-2264.

Rai, D, Y Xia, NJ Hess, DM Strachan, BP McGrail. 2001. "Hydroxo and Chloro Complexes/IonInteractions of $\mathrm{Hf}^{4+}$ and the Solubility Product of $\mathrm{HfO}_{2}(\mathrm{am}) . "$ J. Sol. Chem. 30: 949-967.

Report, J-A C-o P. F. 1999. Japan-Australia Co-operative Program on Research and Development of Technology for the Management of High Level Radioactive Wastes, 1985 to 1998, ANSTO/E736.

Saripalli, KP, BP McGrail, DC Girvin. 2001. Appl. Geochem. 17(5): 649-656.

Strachan, DM, RD Scheele, WC Buchmiller, JD Vienna, RL Sell, and RJ Elovich. 2000. Preparation and Characterization of ${ }^{238} \mathrm{Pu}$-Ceramics for Radiation Damage Experiments, PNNL-13251, Pacific Northwest National Laboratory, Richland, Washington.

Strachan, DM, RD Scheele, JP Icenhower, AE Kozelisky, RL Sell, VL Legore, HT Schaef, MJ O'Hara, CF Brown, and WC Buchmiller. 2001a. The Status of Radiation Damage Experiments, PNNL-13721, Pacific Northwest National Laboratory, Richland, WA.

Strachan, DM, RD Scheele, AE Kozelisky, RL Sell, HT Schaef, MJ O'Hara, CF Brown, and WC Buchmiller. 2001b. Radiation Damage in Titanate Ceramics Used for Plutonium Immobilization, PNNLSA-35541, Pacific Northwest National Laboratory, Richland, WA. 
Strachan, DM, RD Scheele, AE Kozelisky, RL Sell, HT Schaef, MJ O'Hara, CF Brown, and WC Buchmiller. 2002. "Radiation damage in titanate ceramics for plutonium immobilization." Scientific Basis for Nuclear Waste Management XXV 713: 461-468.

Weber, WJ, JW Wad, H Matzke. 1985. Mater. Lett. 3(4): 173-180.

Weber, WJ, JW Wad, H Matzke. 1986. J. Nucl. Mat. 138: 196-209.

Wolery, TJ 1992a. EQ3NR, A Computer Code for Geochemical Aqueous Speciation-Solubility Calculations: Theoretical Manual, Users' Guide and Related Documentation (Version 7.0), UCRL-MA110662 PT III, Lawrence Livermore National Laboratory, Livermore, CA.

Wolery, TJ 1992b. EQ3NR, A Computer Code for Geochemical Aqueous Speciation-Solubility Calculations: Theoretical Manual, Users' Guide and Related Documentation (Version 7.0), UCRL-MA110662 PT III, Lawrence Livermore National Laboratory, Livermore, CA. 


\section{Appendix A}

\section{Individual Ceramics Release Results}




\section{Appendix A: Individual Ceramics Release Results}

Table A.1. Experimental Conditions and Steady-State Effluent Concentrations of Dissolved Elements for Tests with "Pure-Phase" Pyrochlore Ceramics

\begin{tabular}{|c|c|c|c|c|c|c|c|c|c|}
\hline $\begin{array}{l}\text { PY-21 } \\
\text { Expt. \# }\end{array}$ & $\begin{array}{c}\text { Temp. } \\
\left({ }^{\circ} \mathbf{C}\right)\end{array}$ & $\begin{array}{c}\mathbf{p H} \\
\left(25^{\circ} \mathrm{C}\right)\end{array}$ & $\begin{array}{c}\text { Mass } \\
\text { (g) }\end{array}$ & $\begin{array}{c}\text { Average } \\
\text { Flowrate } \\
\left(\mathbf{m}^{3} / \mathbf{s}\right)\end{array}$ & $\begin{array}{c}\text { Average } \\
\text { q/s } \\
(\mathrm{m} / \mathrm{s})\end{array}$ & $\begin{array}{l}\text { Avg. Net } \\
\text { Conc. Gd } \\
\left(\mathrm{g} / \mathrm{m}^{3}\right)\end{array}$ & $\begin{array}{c}\text { Avg. Net } \\
\text { Conc. Ce } \\
\left(\mathrm{g} / \mathrm{m}^{3}\right)\end{array}$ & $\begin{array}{l}\text { Avg. Net } \\
\text { Conc. Ti } \\
\left(\mathrm{g} / \mathrm{m}^{3}\right)\end{array}$ & $\begin{array}{c}\text { Avg. Net } \\
\text { Conc. Ca } \\
\left(\mathbf{g} / \mathbf{m}^{3}\right)\end{array}$ \\
\hline 29 & 90 & 2.0 & 0.504 & $4.39 \mathrm{E}-11$ & $\begin{array}{c}1.53 \mathrm{E}-09 \\
-8.82\end{array}$ & 7.49E-02 & $2.51 \mathrm{E}-01$ & $1.08 \mathrm{E}-02$ & \\
\hline 30 & 90 & 2.0 & 0.503 & $6.58 \mathrm{E}-11$ & $\begin{array}{c}2.29 \mathrm{E}-09 \\
-8.64\end{array}$ & $4.55 \mathrm{E}-02$ & $1.57 \mathrm{E}-01$ & $1.02 \mathrm{E}-02$ & \\
\hline 31 & 90 & 2.0 & 0.515 & $9.06 \mathrm{E}-11$ & $\begin{array}{c}3.08 \mathrm{E}-09 \\
-8.51\end{array}$ & $3.61 \mathrm{E}-02$ & $1.28 \mathrm{E}-01$ & $8.65 \mathrm{E}-03$ & \\
\hline 32 & 90 & 2.0 & 0.511 & $1.10 \mathrm{E}-10$ & $\begin{array}{c}3.77 \mathrm{E}-09 \\
-8.42\end{array}$ & $3.04 \mathrm{E}-02$ & $1.08 \mathrm{E}-01$ & $7.46 \mathrm{E}-03$ & \\
\hline 73 & 90 & 2.0 & 0.508 & $2.12 \mathrm{E}-10$ & $\begin{array}{c}7.30 \mathrm{E}-09 \\
-8.14\end{array}$ & $5.21 \mathrm{E}-02$ & $1.65 \mathrm{E}-01$ & $4.28 \mathrm{E}-03$ & \\
\hline 74 & 90 & 2.0 & 0.352 & $3.07 \mathrm{E}-10$ & $\begin{array}{c}1.53 \mathrm{E}-08 \\
-7.82\end{array}$ & $1.81 \mathrm{E}-02$ & $5.63 \mathrm{E}-02$ & $4.84 \mathrm{E}-03$ & \\
\hline 75 & 90 & 2.0 & 0.224 & $4.29 \mathrm{E}-10$ & $\begin{array}{c}3.35 \mathrm{E}-08 \\
-7.47\end{array}$ & $9.15 \mathrm{E}-03$ & $2.96 \mathrm{E}-02$ & $3.60 \mathrm{E}-03$ & \\
\hline 76 & 90 & 2.0 & 0.153 & $5.38 \mathrm{E}-10$ & $\begin{array}{c}6.17 \mathrm{E}-08 \\
-7.21\end{array}$ & $4.59 \mathrm{E}-03$ & $1.54 \mathrm{E}-02$ & $1.75 \mathrm{E}-03$ & \\
\hline 41 & 90 & 2.0 & $\mathrm{M}$ & $2.16 \mathrm{E}-11$ & $\begin{array}{c}1.69 \mathrm{E}-08 \\
-7.77\end{array}$ & $1.03 \mathrm{E}-02$ & $4.73 \mathrm{E}-02$ & $4.82 \mathrm{E}-03$ & \\
\hline 42 & 90 & 2.0 & $\mathrm{M}$ & $2.16 \mathrm{E}-11$ & $\begin{array}{c}.68 \mathrm{E}-08 \\
-7.78\end{array}$ & $1.23 \mathrm{E}-02$ & $5.29 \mathrm{E}-02$ & 5.94E-02 & \\
\hline 81 & 90 & 2.0 & $\mathrm{M}$ & $1.11 \mathrm{E}-10$ & $\begin{array}{c}5.55 \mathrm{E}-07 \\
-6.26\end{array}$ & $2.11 \mathrm{E}-03$ & $9.90 \mathrm{E}-03$ & & \\
\hline 82 & 90 & 2.0 & $\mathrm{M}$ & $2.27 \mathrm{E}-10$ & $\begin{array}{c}7.06 \mathrm{E}-07 \\
-6.15\end{array}$ & $2.90 \mathrm{E}-03$ & $1.09 \mathrm{E}-02$ & & \\
\hline
\end{tabular}

Notes: "M" stands for monolithic titanate sample. All other specimens are powdered. The value of the $\log$ of $q / S$ is given below the decimal value. Blanks indicate that analyte concentration was not measured. 
Table A.2. Experimental Conditions and Steady-State Effluent Concentrations of Dissolved Elements for Tests with Pyrochlore Baseline ("P-Base") Ceramics

\begin{tabular}{|c|c|c|c|c|c|c|c|c|c|}
\hline $\begin{array}{l}\text { BSL-3 } \\
\text { Expt. \# }\end{array}$ & $\begin{array}{l}\text { Temp. } \\
\left({ }^{\circ} \mathbf{C}\right)\end{array}$ & $\begin{array}{c}\text { pH } \\
\left(25^{\circ} \mathrm{C}\right)\end{array}$ & $\begin{array}{c}\text { Mass } \\
(\mathrm{g})\end{array}$ & $\begin{array}{c}\text { Average } \\
\text { Flowrate } \\
\left(\mathrm{m}^{3} / \mathrm{s}\right)\end{array}$ & $\begin{array}{c}\text { Average } \\
\text { q/s } \\
(\mathbf{m} / \mathbf{s})\end{array}$ & $\begin{array}{l}\text { Avg. Net } \\
\text { Conc. Gd } \\
\left(\mathrm{g} / \mathrm{m}^{\mathbf{3}}\right)\end{array}$ & $\begin{array}{c}\text { Avg. Net } \\
\text { Conc. Ce } \\
\left(\mathrm{g} / \mathrm{m}^{3}\right)\end{array}$ & $\begin{array}{c}\text { Avg. Net } \\
\text { Conc. Ti } \\
\left(\mathrm{g} / \mathrm{m}^{3}\right)\end{array}$ & $\begin{array}{c}\text { Avg. Net } \\
\text { Conc. Ca } \\
\left(\mathbf{g} / \mathbf{m}^{3}\right)\end{array}$ \\
\hline 33 & 90 & 2.0 & 0.512 & $4.57 \mathrm{E}-11$ & $\begin{array}{c}1.57 \mathrm{E}-09 \\
-8.81\end{array}$ & $5.94 \mathrm{E}-01$ & $1.70 \mathrm{E}+00$ & $2.14 \mathrm{E}-02$ & $1.78 \mathrm{E}+00$ \\
\hline 34 & 90 & 2.0 & 0.504 & $6.34 \mathrm{E}-11$ & $\begin{array}{c}2.21 \mathrm{E}-09 \\
-8.66\end{array}$ & $4.29 \mathrm{E}-01$ & $1.31 \mathrm{E}+00$ & $1.77 \mathrm{E}-02$ & $1.35 \mathrm{E}+00$ \\
\hline 35 & 90 & 2.0 & 0.508 & $9.06 \mathrm{E}-11$ & $\begin{array}{c}3.12 \mathrm{E}-09 \\
-8.51\end{array}$ & $3.10 \mathrm{E}-01$ & $1.09 \mathrm{E}+00$ & $1.44 \mathrm{E}-02$ & $8.35 \mathrm{E}-01$ \\
\hline 36 & 90 & 2.0 & 0.509 & $1.11 \mathrm{E}-10$ & $\begin{array}{c}3.83 \mathrm{E}-09 \\
-8.42\end{array}$ & $2.50 \mathrm{E}-01$ & $7.08 \mathrm{E}-01$ & $1.80 \mathrm{E}-02$ & $5.12 \mathrm{E}-01$ \\
\hline 73 & 90 & 2.0 & 0.503 & $2.14 \mathrm{E}-10$ & $\begin{array}{c}7.46 \mathrm{E}-09 \\
-8.13 \\
\end{array}$ & $1.75 \mathrm{E}-01$ & $4.91 \mathrm{E}-01$ & $2.49 \mathrm{E}-02$ & $4.60 \mathrm{E}-01$ \\
\hline 74 & 90 & 2.0 & 0.350 & $3.23 \mathrm{E}-10$ & $\begin{array}{c}1.61 \mathrm{E}-08 \\
-7.79 \\
\end{array}$ & $6.36 \mathrm{E}-02$ & $1.97 \mathrm{E}-01$ & $2.01 \mathrm{E}-02$ & $1.38 \mathrm{E}-01$ \\
\hline 75 & 90 & 2.0 & 0.255 & $4.33 \mathrm{E}-10$ & $\begin{array}{c}2.98 \mathrm{E}-08 \\
-7.53 \\
\end{array}$ & $2.93 \mathrm{E}-02$ & $8.20 \mathrm{E}-02$ & $1.75 \mathrm{E}-02$ & $6.36 \mathrm{E}-02$ \\
\hline 76 & 90 & 2.0 & 0.151 & $5.37 \mathrm{E}-10$ & $\begin{array}{c}6.24 \mathrm{E}-08 \\
-7.21\end{array}$ & $1.23 \mathrm{E}-02$ & $3.59 \mathrm{E}-02$ & $1.12 \mathrm{E}-02$ & $7.60 \mathrm{E}-03$ \\
\hline 43 & 90 & 2.0 & $\mathrm{M}$ & $2.31 \mathrm{E}-11$ & $\begin{array}{c}1.81 \mathrm{E}-08 \\
-7.74\end{array}$ & $1.81 \mathrm{E}-01$ & $6.63 \mathrm{E}-01$ & $1.54 \mathrm{E}-02$ & $3.81 \mathrm{E}+00$ \\
\hline 44 & 90 & 2.0 & $\mathrm{M}$ & $2.31 \mathrm{E}-11$ & $\begin{array}{c}1.77 \mathrm{E}-08 \\
-7.75 \\
\end{array}$ & $1.81 \mathrm{E}-01$ & $6.68 \mathrm{E}-01$ & $1.64 \mathrm{E}-02$ & $3.76 \mathrm{E}+00$ \\
\hline 83 & 90 & 2.0 & $\mathrm{M}$ & $1.05 \mathrm{E}-10$ & $\begin{array}{c}3.15 \mathrm{E}-07 \\
-6.50 \\
\end{array}$ & $2.58 \mathrm{E}-02$ & $5.69 \mathrm{E}-02$ & & \\
\hline 84 & 90 & 2.0 & $\mathrm{M}$ & $2.15 \mathrm{E}-10$ & $\begin{array}{c}6.88 \mathrm{E}-07 \\
-6.16\end{array}$ & $1.81 \mathrm{E}-02$ & $3.59 \mathrm{E}-02$ & & \\
\hline
\end{tabular}

Notes: "M" stands for monolithic titanate sample. All other specimens are powdered. The value of the $\log$ of $q / S$ is given below the decimal value. Blanks indicate that analyte concentration was not measured. 
Table A.3. Experimental Conditions and Steady-State Effluent Concentrations of Dissolved Elements for Tests with Brannerite Ceramics

\begin{tabular}{|c|c|c|c|c|c|c|c|c|c|}
\hline $\begin{array}{l}\text { HCBLx } \\
\text { Expt. \# }\end{array}$ & $\begin{array}{l}\text { Temp. } \\
\left({ }^{\circ} \mathbf{C}\right)\end{array}$ & $\begin{array}{c}\text { pH } \\
\left(25^{\circ} \mathrm{C}\right)\end{array}$ & $\begin{array}{c}\text { Mass } \\
(\mathrm{g}) \\
\end{array}$ & $\begin{array}{c}\text { Average } \\
\text { Flowrate } \\
\left(\mathrm{m}^{3} / \mathrm{s}\right) \\
\end{array}$ & $\begin{array}{c}\text { Average } \\
\text { q/s } \\
(\mathrm{m} / \mathrm{s}) \\
\end{array}$ & $\begin{array}{c}\text { Avg. Net } \\
\text { Conc. Gd } \\
\left(\mathrm{g} / \mathrm{m}^{3}\right) \\
\end{array}$ & $\begin{array}{c}\text { Avg. Net } \\
\text { Conc. Ce } \\
\left(\mathbf{g} / \mathbf{m}^{3}\right) \\
\end{array}$ & $\begin{array}{c}\text { Avg. Net } \\
\text { Conc. Ti } \\
\left(\mathrm{g} / \mathrm{m}^{3}\right) \\
\end{array}$ & $\begin{array}{c}\text { Avg. Net } \\
\text { Conc. Ca } \\
\left(\mathrm{g} / \mathrm{m}^{3}\right)\end{array}$ \\
\hline 47 & 90 & 2.0 & M & $9.93 \mathrm{E}-11$ & $\begin{array}{c}2.75 \mathrm{E}-07 \\
-6.56\end{array}$ & & $1.23 \mathrm{E}-01$ & $6.66 \mathrm{E}-03$ & \\
\hline 51 & 90 & 2.0 & $\mathrm{M}$ & $1.06 \mathrm{E}-10$ & $\begin{array}{c}2.94 \mathrm{E}-07 \\
-6.53\end{array}$ & & $1.22 \mathrm{E}+00$ & $2.36 \mathrm{E}-02$ & \\
\hline 87 & 90 & 2.0 & $\mathrm{M}$ & $1.07 \mathrm{E}-10$ & $\begin{array}{c}2.90 \mathrm{E}-07 \\
-6.54\end{array}$ & & $7.97 \mathrm{E}-02$ & & \\
\hline 88 & 90 & 2.0 & $\mathrm{M}$ & $2.33 \mathrm{E}-10$ & $\begin{array}{c}6.55 \mathrm{E}-07 \\
-6.18\end{array}$ & & $6.18 \mathrm{E}-02$ & & \\
\hline
\end{tabular}

Notes: "M" stands for monolithic titanate sample. All other specimens are powdered. The value of the $\log$ of $q / S$ is given below the decimal value. Blanks indicate that analyte concentration was not measured.

Table A.4. Experimental Conditions and Steady-State Effluent Concentrations of Dissolved Elements for Tests with Pyrochlore Ceramics

\begin{tabular}{|c|c|c|c|c|c|c|c|c|c|}
\hline $\begin{array}{l}\text { PY-17 } \\
\text { Expt. \# } \\
\end{array}$ & $\begin{array}{c}\text { Temp. } \\
\left({ }^{\circ} \mathrm{C}\right) \\
\end{array}$ & $\begin{array}{c}\text { pH } \\
\left(25^{\circ} \mathrm{C}\right) \\
\end{array}$ & $\begin{array}{c}\text { Mass } \\
(\mathrm{g}) \\
\end{array}$ & $\begin{array}{c}\text { Average } \\
\text { Flowrate } \\
\left(\mathrm{m}^{3} / \mathrm{s}\right) \\
\end{array}$ & $\begin{array}{c}\text { Average } \\
\mathbf{q} / \mathbf{s} \\
(\mathbf{m} / \mathbf{s}) \\
\end{array}$ & $\begin{array}{c}\text { Avg. Net } \\
\text { Conc. Gd } \\
\left(\mathrm{g} / \mathrm{m}^{3}\right) \\
\end{array}$ & $\begin{array}{c}\text { Avg. Net } \\
\text { Conc. Ce } \\
\left(\mathrm{g} / \mathrm{m}^{3}\right)\end{array}$ & $\begin{array}{c}\text { Avg. Net } \\
\text { Conc. Ti } \\
\left(\mathrm{g} / \mathrm{m}^{3}\right) \\
\end{array}$ & $\begin{array}{c}\text { Avg. Net } \\
\text { Conc. Ca } \\
\left(\mathrm{g} / \mathrm{m}^{3}\right)\end{array}$ \\
\hline 49 & 90 & 2.0 & $\mathrm{M}$ & $1.18 \mathrm{E}-10$ & $\begin{array}{c}5.54 \mathrm{E}-07 \\
-6.26\end{array}$ & 2.07E-02 & $9.00 \mathrm{E}-02$ & $1.97 \mathrm{E}-02$ & \\
\hline $17 \mathrm{~A}$ & 90 & 2.0 & $\mathrm{M}$ & $5.79 \mathrm{E}-12$ & $\begin{array}{c}1.48 \mathrm{E}-07 \\
-6.83\end{array}$ & $3.59 \mathrm{E}-02$ & $1.19 \mathrm{E}-01$ & $5.06 \mathrm{E}-02$ & \\
\hline 17B & 90 & 2.0 & M & $5.79 \mathrm{E}-12$ & $\begin{array}{c}1.46 \mathrm{E}-07 \\
-6.84\end{array}$ & $4.04 \mathrm{E}-02$ & $1.29 \mathrm{E}-01$ & $5.88 \mathrm{E}-02$ & \\
\hline 91 & 90 & 2.0 & M & $1.13 \mathrm{E}-10$ & $\begin{array}{c}5.14 \mathrm{E}-07 \\
-6.29\end{array}$ & $5.10 \mathrm{E}-03$ & $1.44 \mathrm{E}-02$ & & \\
\hline 92 & 90 & 2.0 & $\mathrm{M}$ & $2.11 \mathrm{E}-10$ & $\begin{array}{c}9.66 \mathrm{E}-07 \\
-6.02\end{array}$ & $5.03 \mathrm{E}-03$ & $1.35 \mathrm{E}-02$ & & \\
\hline
\end{tabular}

Notes: "M" stands for monolithic titanate sample. All other specimens are powdered. The value of the $\log$ of $q / S$ is given below the decimal value. Blanks indicate that analyte concentration was not measured. 
Table A.5. Experimental Conditions and Steady-State Effluent Concentrations of Dissolved Elements for Tests with Pyrochlore Baseline Ceramics

\begin{tabular}{|c||c|c|c|c|c|c|c|c|c||}
\hline HBAS-6 & $\begin{array}{c}\text { Temp. } \\
\left({ }^{\circ} \mathbf{C}\right)\end{array}$ & $\begin{array}{c}\mathbf{p H} \\
\left(\mathbf{2 5}{ }^{\circ} \mathbf{C}\right)\end{array}$ & $\begin{array}{c}\text { Mass } \\
(\mathbf{g})\end{array}$ & $\begin{array}{c}\text { Average } \\
\text { Flowrate } \\
\left(\mathbf{m}^{\mathbf{3}} / \mathbf{s}\right)\end{array}$ & $\begin{array}{c}\text { Average } \\
\mathbf{q} / \mathbf{s} \\
(\mathbf{m} / \mathbf{s})\end{array}$ & $\begin{array}{c}\text { Avg. Net } \\
\mathbf{C o n c} \text {. Gd } \\
\left(\mathbf{g} / \mathbf{m}^{\mathbf{3}}\right)\end{array}$ & $\begin{array}{c}\text { Avg. Net } \\
\mathbf{C o n c} \text { Ce } \\
\left(\mathbf{g} / \mathbf{m}^{\mathbf{3}}\right)\end{array}$ & $\begin{array}{c}\text { Avg. Net } \\
\mathbf{C o n c} \text {. Ti } \\
\left(\mathbf{g} / \mathbf{m}^{\mathbf{3}}\right)\end{array}$ & $\begin{array}{c}\text { Avg. Net } \\
\mathbf{C o n c} \text { Ca } \\
\left(\mathbf{g} / \mathbf{m}^{\mathbf{3}}\right)\end{array}$ \\
\hline \hline \multirow{2}{*}{46} & 90 & 2.0 & $\mathrm{M}$ & $1.10 \mathrm{E}-10$ & $\begin{array}{c}3.35 \mathrm{E}-07 \\
-6.48\end{array}$ & $2.60 \mathrm{E}-02$ & $4.27 \mathrm{E}-02$ & $3.13 \mathrm{E}-02$ & $2.78 \mathrm{E}+00$ \\
\hline 50 & 90 & 2.0 & $\mathrm{M}$ & $1.27 \mathrm{E}-10$ & $\begin{array}{c}3.96 \mathrm{E}-07 \\
-6.40\end{array}$ & $1.95 \mathrm{E}-02$ & $8.80 \mathrm{E}-02$ & $5.27 \mathrm{E}-02$ & $2.96 \mathrm{E}+00$ \\
\hline 89 & 90 & 2.0 & $\mathrm{M}$ & $1.12 \mathrm{E}-10$ & $\begin{array}{c}3.45 \mathrm{E}-07 \\
-6.46\end{array}$ & $1.34 \mathrm{E}-02$ & $3.28 \mathrm{E}-02$ & $0.00 \mathrm{E}+00$ & $0.00 \mathrm{E}+00$ \\
\hline 90 & 90 & 2.0 & $\mathrm{M}$ & $2.23 \mathrm{E}-10$ & $\begin{array}{c}6.93 \mathrm{E}-07 \\
-6.16\end{array}$ & $8.05 \mathrm{E}-03$ & $1.97 \mathrm{E}-02$ & $0.00 \mathrm{E}+00$ & $0.00 \mathrm{E}+00$ \\
\hline \hline
\end{tabular}

Notes: "M" stands for monolithic titanate sample. All other specimens are powdered. The value of the $\log$ of $q / S$ is given below the decimal value.

Table A.6. Experimental Conditions and Steady-State Effluent Concentrations of Dissolved Elements for Tests with Zirconolite Ceramics

\begin{tabular}{|c|c|c|c|c|c|c|c|c|c|}
\hline $\begin{array}{c}\text { HZirc5x } \\
\text { Expt. \# }\end{array}$ & $\begin{array}{c}\text { Temp. } \\
\left({ }^{\circ} \mathrm{C}\right)\end{array}$ & $\begin{array}{c}\text { pH } \\
\left(25^{\circ} \mathrm{C}\right)\end{array}$ & $\begin{array}{c}\text { Mass } \\
\text { (g) }\end{array}$ & $\begin{array}{c}\text { Average } \\
\text { Flowrate } \\
\left(\mathrm{m}^{3} / \mathrm{s}\right)\end{array}$ & $\begin{array}{c}\text { Average } \\
q / \mathbf{s} \\
(\mathrm{m} / \mathrm{s})\end{array}$ & $\begin{array}{c}\text { Avg. Net } \\
\text { Conc. Gd } \\
\left(\mathrm{g} / \mathrm{m}^{3}\right)\end{array}$ & $\begin{array}{c}\text { Avg. Net } \\
\text { Conc. Ce } \\
\left(\mathrm{g} / \mathrm{m}^{3}\right)\end{array}$ & $\begin{array}{c}\text { Avg. Net } \\
\text { Conc. Ti } \\
\left(\mathrm{g} / \mathrm{m}^{3}\right)\end{array}$ & $\begin{array}{c}\text { Avg. Net } \\
\text { Conc. Ca } \\
\left(\mathrm{g} / \mathrm{m}^{3}\right)\end{array}$ \\
\hline 48 & 90 & 2.0 & M & $1.13 \mathrm{E}-10$ & $\begin{array}{c}3.57 \mathrm{E}-07 \\
-6.45\end{array}$ & $1.03 \mathrm{E}-03$ & $6.93 \mathrm{E}-03$ & $1.20 \mathrm{E}-03$ & $9.70 \mathrm{E}-03$ \\
\hline 52 & 90 & 2.0 & $\mathrm{M}$ & $1.13 \mathrm{E}-10$ & $\begin{array}{c}3.76 \mathrm{E}-07 \\
-6.43\end{array}$ & $9.95 \mathrm{E}-04$ & $7.82 \mathrm{E}-03$ & $2.13 \mathrm{E}-03$ & $0.00 \mathrm{E}+00$ \\
\hline 85 & 90 & 2.0 & $\mathrm{M}$ & $1.10 \mathrm{E}-10$ & $\begin{array}{c}3.58 \mathrm{E}-07 \\
-6.45\end{array}$ & $8.04 \mathrm{E}-04$ & $5.19 \mathrm{E}-03$ & $0.00 \mathrm{E}+00$ & $0.00 \mathrm{E}+00$ \\
\hline 86 & 90 & 2.0 & $\mathrm{M}$ & $2.16 \mathrm{E}-10$ & $\begin{array}{c}6.98 \mathrm{E}-07 \\
-6.16\end{array}$ & $4.78 \mathrm{E}-04$ & $3.58 \mathrm{E}-03$ & $0.00 \mathrm{E}+00$ & $0.00 \mathrm{E}+00$ \\
\hline
\end{tabular}

Table A.7. Experimental Conditions and Steady-State Effluent Concentrations of Dissolved Elements for Tests with ${ }^{238} \mathrm{Pu}$-Bearing Pyrochlore Baseline Ceramics

\begin{tabular}{|c|c|c|c|c|c|c|c|c|c|}
\hline $\begin{array}{c}\text { 238-Pbas } \\
\text { Expt. \# }\end{array}$ & $\begin{array}{c}\text { Temp. } \\
\left({ }^{\circ} \mathbf{C}\right)\end{array}$ & $\begin{array}{c}\text { pH } \\
\left(25^{\circ} \mathrm{C}\right) \\
\end{array}$ & $\begin{array}{c}\text { Mass } \\
(\mathrm{g}) \\
\end{array}$ & $\begin{array}{c}\text { Average } \\
\text { Flowrate } \\
\left(\mathrm{m}^{3} / \mathbf{s}\right) \\
\end{array}$ & $\begin{array}{c}\text { Average } \\
\mathbf{q} / \mathbf{s} \\
(\mathbf{m} / \mathbf{s}) \\
\end{array}$ & $\begin{array}{c}\text { Avg. Net } \\
\text { Conc. Gd } \\
\left(\mathrm{g} / \mathrm{m}^{\mathbf{3}}\right) \\
\end{array}$ & $\begin{array}{c}\text { Avg. Net } \\
\text { Conc. U } \\
\left(\mathbf{g} / \mathbf{m}^{3}\right) \\
\end{array}$ & $\begin{array}{c}\text { Avg. Net } \\
\text { Conc. Ti } \\
\left(\mathrm{g} / \mathrm{m}^{3}\right) \\
\end{array}$ & $\begin{array}{c}\text { Avg. Net } \\
\text { Conc. Pu } \\
\left(\mathbf{g} / \mathbf{m}^{3}\right) \\
\end{array}$ \\
\hline $239-1$ & 90 & 2.0 & 0.250 & 2.31E-11 & $\begin{array}{c}7.19 \mathrm{E}-10 \\
-9.14\end{array}$ & $2.22 \mathrm{E}-01$ & $2.77 \mathrm{E}+01$ & $1.13 \mathrm{E}-01$ & $1.91 \mathrm{E}+00$ \\
\hline
\end{tabular}

Notes: "M" stands for monolithic titanate sample. All other specimens are powdered. The value of the $\log$ of $q / S$ is given below the decimal value. 
Table A.8. Experimental Conditions and Steady-State Effluent Concentrations of Dissolved Elements for Tests with Zirconolite Ceramics

\begin{tabular}{|c|c|c|c|c|c|c|c|c|c|}
\hline $\begin{array}{l}\text { CeZirc6 } \\
\text { Expt. \# }\end{array}$ & $\begin{array}{c}\text { Temp. } \\
\left({ }^{\circ} \mathbf{C}\right)\end{array}$ & $\begin{array}{c}\text { pH } \\
\left(25^{\circ} \mathrm{C}\right)\end{array}$ & $\begin{array}{c}\text { Mass } \\
(\mathrm{g})\end{array}$ & $\begin{array}{c}\text { Average } \\
\text { Flowrate } \\
\left(\mathrm{m}^{3} / \mathrm{s}\right)\end{array}$ & $\begin{array}{c}\text { Average } \\
\text { q/s } \\
(\mathrm{m} / \mathrm{s})\end{array}$ & $\begin{array}{c}\text { Avg. Net } \\
\text { Conc. Gd } \\
\left(\mathrm{g} / \mathrm{m}^{3}\right)\end{array}$ & $\begin{array}{c}\text { Avg. Net } \\
\text { Conc. Ce } \\
\left(\mathrm{g} / \mathrm{m}^{3}\right)\end{array}$ & $\begin{array}{c}\text { Avg. Net } \\
\text { Conc. Ti } \\
\left(\mathrm{g} / \mathrm{m}^{3}\right)\end{array}$ & $\begin{array}{c}\text { Avg. Net } \\
\text { Conc. Mo } \\
\left(\mathrm{g} / \mathrm{m}^{3}\right)\end{array}$ \\
\hline 57 & 90 & 2.0 & 1.000 & $2.31 \mathrm{E}-11$ & $\begin{array}{c}1.81 \mathrm{E}-10 \\
-9.74\end{array}$ & $5.83 \mathrm{E}-03$ & $7.64 \mathrm{E}-02$ & $4.86 \mathrm{E}-03$ & $0.00 \mathrm{E}+00$ \\
\hline 59 & 90 & 7.0 & 1.000 & $2.31 \mathrm{E}-11$ & $\begin{array}{c}1.81 \mathrm{E}-10 \\
-9.74\end{array}$ & $0.00 \mathrm{E}+00$ & $0.00 \mathrm{E}+00$ & $0.00 \mathrm{E}+00$ & $9.70 \mathrm{E}-03$ \\
\hline 61 & 90 & 8.0 & 0.508 & $2.31 \mathrm{E}-11$ & $\begin{array}{c}1.81 \mathrm{E}-10 \\
-9.74\end{array}$ & $0.00 \mathrm{E}+00$ & $0.00 \mathrm{E}+00$ & $0.00 \mathrm{E}+00$ & $3.43 \mathrm{E}-03$ \\
\hline 62 & 90 & 9.0 & 1.002 & $2.31 \mathrm{E}-11$ & $\begin{array}{c}1.81 \mathrm{E}-10 \\
-9.74\end{array}$ & $0.00 \mathrm{E}+00$ & $0.00 \mathrm{E}+00$ & $0.00 \mathrm{E}+00$ & $3.28 \mathrm{E}-03$ \\
\hline 63 & 90 & 10.0 & 1.002 & $2.31 \mathrm{E}-11$ & $\begin{array}{c}1.81 \mathrm{E}-10 \\
-9.74\end{array}$ & $0.00 \mathrm{E}+00$ & $0.00 \mathrm{E}+00$ & $0.00 \mathrm{E}+00$ & $4.54 \mathrm{E}-03$ \\
\hline
\end{tabular}

Notes: "M" stands for monolithic titanate sample. All other specimens are powdered. The value of the $\log$ of $q / S$ is given below the decimal value.

Table A.9. Experimental Conditions and Steady-State Effluent Concentrations of Dissolved Elements for Tests with ${ }^{239} \mathrm{Pu}$-Bearing Zirconolite Ceramics

\begin{tabular}{|c|c|c|c|c|c|c|c|c|c|}
\hline $\begin{array}{l}\text { Zirc-1 } \\
\text { Expt. \# }\end{array}$ & $\begin{array}{c}\text { Temp. } \\
\left({ }^{\circ} \mathbf{C}\right)\end{array}$ & $\begin{array}{c}\text { pH } \\
\left(25^{\circ} \mathrm{C}\right)\end{array}$ & $\begin{array}{c}\text { Mass } \\
(\mathrm{g})\end{array}$ & $\begin{array}{c}\text { Average } \\
\text { Flowrate } \\
\left(\mathrm{m}^{3} / \mathrm{s}\right)\end{array}$ & $\begin{array}{c}\text { Average } \\
\text { q/s } \\
(\mathrm{m} / \mathbf{s})\end{array}$ & $\begin{array}{c}\text { Avg. Net } \\
\text { Conc. Gd } \\
\left(\mathrm{g} / \mathrm{m}^{3}\right)\end{array}$ & $\begin{array}{c}\text { Avg. Net } \\
\text { Conc. U } \\
\left(\mathbf{g} / \mathbf{m}^{3}\right)\end{array}$ & $\begin{array}{c}\text { Avg. Net } \\
\text { Conc. Ti } \\
\left(\mathrm{g} / \mathrm{m}^{3}\right)\end{array}$ & $\begin{array}{c}\text { Avg. Net } \\
\text { Conc. Mo } \\
\left(\mathrm{g} / \mathrm{m}^{3}\right)\end{array}$ \\
\hline 1 & 90 & 2.0 & 0.500 & $2.31 \mathrm{E}-11$ & $\begin{array}{c}3.62 \mathrm{E}-10 \\
-9.44\end{array}$ & $2.24 \mathrm{E}-02$ & $3.93 \mathrm{E}-02$ & $1.12 \mathrm{E}-01$ & $1.61 \mathrm{E}-03$ \\
\hline 2 & 90 & 5.7 & 0.500 & $2.31 \mathrm{E}-11$ & $\begin{array}{c}3.62 \mathrm{E}-10 \\
-9.44\end{array}$ & & $1.36 \mathrm{E}-01$ & $1.61 \mathrm{E}-03$ & $4.55 \mathrm{E}-03$ \\
\hline 3 & 90 & 7.0 & 0.500 & $2.31 \mathrm{E}-11$ & $\begin{array}{c}3.62 \mathrm{E}-10 \\
-9.44\end{array}$ & & 7.83E-02 & $2.12 \mathrm{E}-03$ & $3.76 \mathrm{E}-03$ \\
\hline 4 & 90 & 8.0 & 0.500 & $2.31 \mathrm{E}-11$ & $\begin{array}{c}3.62 \mathrm{E}-10 \\
-9.44\end{array}$ & & $1.18 \mathrm{E}-01$ & $1.42 \mathrm{E}-03$ & $1.86 \mathrm{E}-03$ \\
\hline 5 & 90 & 9.0 & 0.500 & $2.31 \mathrm{E}-11$ & $\begin{array}{c}3.62 \mathrm{E}-10 \\
-9.44\end{array}$ & & $2.60 \mathrm{E}-01$ & $2.16 \mathrm{E}-03$ & $1.60 \mathrm{E}-03$ \\
\hline 6 & 90 & 10.0 & 0.500 & $2.31 \mathrm{E}-11$ & $\begin{array}{c}3.62 \mathrm{E}-10 \\
-9.44\end{array}$ & & $4.97 \mathrm{E}-02$ & $1.49 \mathrm{E}-03$ & $3.57 \mathrm{E}-04$ \\
\hline 7 & 90 & 11.0 & 0.500 & $2.31 \mathrm{E}-11$ & $\begin{array}{c}3.62 \mathrm{E}-10 \\
-9.44\end{array}$ & & $1.04 \mathrm{E}-01$ & $1.19 \mathrm{E}-03$ & $6.93 \mathrm{E}-04$ \\
\hline
\end{tabular}

Notes: "M" stands for monolithic titanate sample. All other specimens are powdered. The value of the $\log$ of $q / S$ is given below the decimal value. Blanks indicate that analyte concentration was not measured. 
Table A.10. Experimental Conditions and Steady-State Effluent Concentrations of Dissolved Elements for Tests with ${ }^{238} \mathrm{Pu}$-Bearing Pyrochlore Baseline (annealed and unannealed), Pyrochlore, and Zirconolite Ceramics

\begin{tabular}{|c|c|c|c|c|c|c|c|c|c|}
\hline $\begin{array}{l}\text { 238-Pu } \\
\text { Expt. \# }\end{array}$ & $\begin{array}{c}\text { Temp. } \\
\left({ }^{\circ} \mathbf{C}\right)\end{array}$ & $\begin{array}{c}\text { pH } \\
\left(25^{\circ} \mathrm{C}\right)\end{array}$ & $\begin{array}{c}\text { Mass } \\
(\mathrm{g})\end{array}$ & $\begin{array}{c}\text { Average } \\
\text { Flowrate } \\
\left(\mathrm{m}^{3} / \mathrm{s}\right)\end{array}$ & $\begin{array}{c}\text { Average } \\
\mathbf{q} / \mathbf{s} \\
(\mathrm{m} / \mathbf{s})\end{array}$ & $\begin{array}{c}\text { Avg. Net } \\
\text { Conc. Gd } \\
\left(\mathrm{g} / \mathrm{m}^{3}\right)\end{array}$ & $\begin{array}{c}\text { Avg. Net } \\
\text { Conc. U } \\
\left(\mathrm{g} / \mathrm{m}^{3}\right)\end{array}$ & $\begin{array}{c}\text { Avg. Net } \\
\text { Conc. Ti } \\
\left(\mathrm{g} / \mathrm{m}^{3}\right)\end{array}$ & $\begin{array}{c}\text { Avg. Net } \\
\text { Conc. Pu } \\
\left(\mathrm{g} / \mathrm{m}^{3}\right)\end{array}$ \\
\hline $\begin{array}{c}238-2 \\
\text { Pbase-a }\end{array}$ & 85 & 2.0 & 0.246 & $2.18 \mathrm{E}-10$ & $\begin{array}{c}6.91 \mathrm{E}-09 \\
-8.16\end{array}$ & $5.18 \mathrm{E}-02$ & $2.96 \mathrm{E}-01$ & $0.00 \mathrm{E}+00$ & 5.79E-02 \\
\hline $\begin{array}{c}238-1 \\
\text { Pbase-u }\end{array}$ & 85 & 2.0 & 0.242 & $2.06 \mathrm{E}-10$ & $\begin{array}{c}6.64 \mathrm{E}-09 \\
-8.18\end{array}$ & $3.93 \mathrm{E}-02$ & $2.44 \mathrm{E}-01$ & $0.00 \mathrm{E}+00$ & $3.99 \mathrm{E}-02$ \\
\hline $\begin{array}{c}238-3 \\
\text { Pyro-a }\end{array}$ & 85 & 2.0 & 0.247 & $2.14 \mathrm{E}-10$ & $\begin{array}{c}6.77 \mathrm{E}-09 \\
-8.17\end{array}$ & $3.12 \mathrm{E}-02$ & $2.79 \mathrm{E}-01$ & $0.00 \mathrm{E}+00$ & $3.82 \mathrm{E}-02$ \\
\hline $\begin{array}{l}238-4 \\
\text { Zirc-a }\end{array}$ & 85 & 2.0 & 0.244 & $2.12 \mathrm{E}-10$ & $\begin{array}{c}6.79 \mathrm{E}-09 \\
-8.17\end{array}$ & $3.12 \mathrm{E}-02$ & $5.72 \mathrm{E}-01$ & $0.00 \mathrm{E}+00$ & $4.26 \mathrm{E}-02$ \\
\hline
\end{tabular}

Notes: "M" stands for monolithic titanate sample. All other specimens are powdered. The value of the $\log$ of $q / S$ is given below the decimal value.

Table A.11. Experimental Conditions and Steady-State Effluent Concentrations of Dissolved Elements for Tests with ${ }^{239}$ Pu-Bearing Pyrochlore Baseline ("P-Base") Ceramics

\begin{tabular}{|c|c|c|c|c|c|c|c|c|c|}
\hline $\begin{array}{c}\text { 239-Pbas } \\
\text { Expt. \# }\end{array}$ & $\begin{array}{c}\text { Temp. } \\
\left({ }^{\circ} \mathrm{C}\right)\end{array}$ & $\begin{array}{c}\text { pH } \\
\left(25^{\circ} \mathrm{C}\right) \\
\end{array}$ & $\begin{array}{c}\text { Mass } \\
(\mathrm{g}) \\
\end{array}$ & $\begin{array}{c}\text { Average } \\
\text { Flowrate } \\
\left(\mathrm{m}^{3} / \mathrm{s}\right)\end{array}$ & $\begin{array}{c}\text { Average } \\
\mathbf{q} / \mathbf{s} \\
(\mathbf{m} / \mathbf{s}) \\
\end{array}$ & $\begin{array}{c}\text { Avg. Net } \\
\text { Conc. Gd } \\
\left(\mathrm{g} / \mathrm{m}^{3}\right)\end{array}$ & $\begin{array}{c}\text { Avg. Net } \\
\text { Conc. U } \\
\left(\mathrm{g} / \mathrm{m}^{3}\right) \\
\end{array}$ & $\begin{array}{c}\text { Avg. Net } \\
\text { Conc. Ti } \\
\left(\mathrm{g} / \mathrm{m}^{3}\right) \\
\end{array}$ & $\begin{array}{c}\text { Avg. Net } \\
\text { Conc. Pu } \\
\left(\mathrm{g} / \mathrm{m}^{3}\right) \\
\end{array}$ \\
\hline $239-1$ & 90 & 2.0 & 0.500 & $2.16 \mathrm{E}-11$ & $\begin{array}{c}3.38 \mathrm{E}-10 \\
-9.47\end{array}$ & $4.01 \mathrm{E}-02$ & $1.08 \mathrm{E}-01$ & $1.92 \mathrm{E}-02$ & $2.77 \mathrm{E}-02$ \\
\hline $239-2$ & 90 & 7.0 & 0.500 & $2.14 \mathrm{E}-11$ & $\begin{array}{c}3.34 \mathrm{E}-10 \\
-9.48 \\
\end{array}$ & & $3.14 \mathrm{E}-02$ & & \\
\hline $239-3$ & 90 & 8.0 & 0.500 & $2.23 \mathrm{E}-11$ & $\begin{array}{c}3.49 \mathrm{E}-10 \\
-9.46\end{array}$ & & $1.94 \mathrm{E}-02$ & & \\
\hline $239-4$ & 90 & 9.0 & 0.500 & $2.09 \mathrm{E}-11$ & $\begin{array}{c}3.27 \mathrm{E}-10 \\
-9.49 \\
\end{array}$ & & $2.00 \mathrm{E}-02$ & & \\
\hline $239-5$ & 90 & 10.0 & 0.500 & $2.22 \mathrm{E}-11$ & $\begin{array}{c}3.47 \mathrm{E}-10 \\
-9.46\end{array}$ & & $1.67 \mathrm{E}-02$ & & \\
\hline $239-6$ & 90 & 11.0 & 0.500 & $2.21 \mathrm{E}-11$ & $\begin{array}{c}7.08 \mathrm{E}-10 \\
-9.15\end{array}$ & & $2.57 \mathrm{E}-02$ & & \\
\hline
\end{tabular}

Notes: "M" stands for monolithic titanate sample. All other specimens are powdered. Blanks indicate that analyte concentration was not measured. The value of the $\log$ of $q / S$ is given below the decimal value. 
Table A.12. Steady-State Dissolution Rates and Associated 1 $\sigma$-Error for "Pure Phase" Pyrochlore Ceramics

\begin{tabular}{|c|c|c|c|c|c|c|c|c|c|}
\hline $\begin{array}{l}\text { PY-21 } \\
\text { Expt. \# }\end{array}$ & $\begin{array}{l}\text { Average } \\
\text { Gd Rate } \\
\left(\mathrm{g} / \mathrm{m}^{2} / \mathrm{d}\right)\end{array}$ & $\begin{array}{c}\text { B Rate } \\
\text { Error } \\
\left(\mathrm{g} / \mathrm{m}^{2} / \mathrm{d}\right)\end{array}$ & $\begin{array}{l}\text { Average } \\
\text { Ce Rate } \\
\left(\mathrm{g} / \mathrm{m}^{2} / \mathrm{d}\right)\end{array}$ & $\begin{array}{c}\text { Ce Rate } \\
\text { Error } \\
\left(\mathrm{g} / \mathrm{m}^{2} / \mathrm{d}\right)\end{array}$ & $\begin{array}{c}\text { Average } \\
\text { Ti Rate } \\
\left(\mathrm{g} / \mathrm{m}^{2} / \mathbf{d}\right)\end{array}$ & $\begin{array}{c}\text { Ti Rate } \\
\text { Error } \\
\left(\mathrm{g} / \mathrm{m}^{2} / \mathbf{d}\right)\end{array}$ & $\begin{array}{l}\text { Average } \\
\text { Ca Rate } \\
\left(\mathrm{g} / \mathrm{m}^{2} / \mathrm{d}\right)\end{array}$ & $\begin{array}{c}\text { Ca Rate } \\
\text { Error } \\
\left(\mathrm{g} / \mathrm{m}^{2} / \mathrm{d}\right)\end{array}$ & Notes \\
\hline 29 & $\begin{array}{c}8.56 \mathrm{E}-05 \\
-4.07\end{array}$ & $(1.96 \mathrm{E}-05)$ & $\begin{array}{c}1.15 \mathrm{E}-04 \\
-3.94\end{array}$ & $(2.64 \mathrm{E}-05)$ & $\begin{array}{c}5.94 \mathrm{E}-06 \\
-5.23\end{array}$ & $(1.36 \mathrm{E}-06)$ & & & 1 \\
\hline 30 & $\begin{array}{c}7.81 \mathrm{E}-05 \\
-4.11\end{array}$ & $(1.79 \mathrm{E}-05)$ & $\begin{array}{c}1.08 \mathrm{E}-04 \\
-3.97\end{array}$ & $(2.47 \mathrm{E}-05)$ & $\begin{array}{c}8.42 \mathrm{E}-06 \\
-5.07\end{array}$ & $(1.93 \mathrm{E}-06)$ & & & 1 \\
\hline 31 & $\begin{array}{c}8.32 \mathrm{E}-05 \\
-4.08\end{array}$ & (1.91E-05) & $\begin{array}{c}1.18 \mathrm{E}-04 \\
-3.93\end{array}$ & $(2.71 \mathrm{E}-05)$ & $\begin{array}{c}9.63 \mathrm{E}-06 \\
-5.02\end{array}$ & $(2.21 \mathrm{E}-06)$ & & & 1 \\
\hline 32 & $\begin{array}{c}8.57 \mathrm{E}-05 \\
-4.07\end{array}$ & (1.96E-05) & $\begin{array}{c}1.22 \mathrm{E}-04 \\
-3.91\end{array}$ & $(2.80 \mathrm{E}-05)$ & $\begin{array}{c}1.02 \mathrm{E}-05 \\
-4.99\end{array}$ & $(2.33 \mathrm{E}-06)$ & & & 1 \\
\hline 73 & $\begin{array}{c}2.85 \mathrm{E}-04 \\
-3.55\end{array}$ & (6.52E-05) & $\begin{array}{c}3.61 \mathrm{E}-04 \\
-3.44\end{array}$ & $(8.28 \mathrm{E}-05)$ & $\begin{array}{c}1.13 \mathrm{E}-05 \\
-4.95\end{array}$ & $(2.59 \mathrm{E}-06)$ & & & 1 \\
\hline 74 & $\begin{array}{c}2.06 \mathrm{E}-04 \\
-3.69\end{array}$ & (4.73E-05) & $\begin{array}{c}2.58 \mathrm{E}-04 \\
-3.59\end{array}$ & $(5.91 \mathrm{E}-05)$ & $\begin{array}{c}2.67 \mathrm{E}-05 \\
-4.57\end{array}$ & $(6.12 \mathrm{E}-06)$ & & & 1 \\
\hline 75 & $\begin{array}{c}2.30 \mathrm{E}-04 \\
-3.64\end{array}$ & $(5.27 \mathrm{E}-05)$ & $\begin{array}{c}2.98 \mathrm{E}-04 \\
-3.53\end{array}$ & $(6.84 \mathrm{E}-05)$ & $\begin{array}{c}4.36 \mathrm{E}-05 \\
-4.36\end{array}$ & $(1.00 \mathrm{E}-05)$ & & & 1 \\
\hline 76 & $\begin{array}{c}2.12 \mathrm{E}-04 \\
-3.67\end{array}$ & (4.88E-05) & $\begin{array}{c}2.85 \mathrm{E}-04 \\
-3.55\end{array}$ & $(6.56 \mathrm{E}-05)$ & $\begin{array}{c}3.90 \mathrm{E}-05 \\
-4.41\end{array}$ & (8.98E-06) & & & 1 \\
\hline 41 & $\begin{array}{c}1.30 \mathrm{E}-04 \\
-3.89\end{array}$ & (2.99E-05) & $\begin{array}{c}2.40 \mathrm{E}-04 \\
-3.62\end{array}$ & (5.52E-05) & $\begin{array}{c}2.94 \mathrm{E}-05 \\
-4.53\end{array}$ & (6.78E-06) & & & $\mathrm{M}$ \\
\hline 42 & $\begin{array}{c}1.54 \mathrm{E}-04 \\
-3.81\end{array}$ & $(3.54 \mathrm{E}-05)$ & $\begin{array}{c}2.66 \mathrm{E}-04 \\
-3.58\end{array}$ & $(6.12 \mathrm{E}-05)$ & $\begin{array}{c}3.60 \mathrm{E}-04 \\
-3.44\end{array}$ & $(8.28 \mathrm{E}-05)$ & & & $\mathrm{M}$ \\
\hline 81 & $\begin{array}{c}8.76 \mathrm{E}-04 \\
-3.06\end{array}$ & (2.01E-04) & $\begin{array}{c}1.65 \mathrm{E}-03 \\
-2.78\end{array}$ & (3.78E-04) & & & & & $\mathrm{M}$ \\
\hline 82 & $\begin{array}{c}1.53 \mathrm{E}-03 \\
-2.81\end{array}$ & $(3.52 \mathrm{E}-04)$ & $\begin{array}{c}2.31 \mathrm{E}-03 \\
-2.64\end{array}$ & $(5.30 \mathrm{E}-04)$ & & & & & $\mathrm{M}$ \\
\hline
\end{tabular}

Notes: $1=$ powdered specimen with a specific surface area of $0.128 \mathrm{~m}^{2} \mathrm{~g}^{-1} . \mathrm{M}=$ monolithic specimen. The value of the log of the rate is given below the decimal value. Blanks indicate that rate could not be determined due to analyte concentration not measured. 
Table A.13. Steady-State Dissolution Rates and Associated 1 $\sigma$-Error for Pyrochlore Baseline Ceramics

\begin{tabular}{|c|c|c|c|c|c|c|c|c|c|}
\hline $\begin{array}{l}\text { BSL-3 } \\
\text { Expt. \# }\end{array}$ & $\begin{array}{c}\text { Average } \\
\text { Gd Rate } \\
\left(\mathrm{g} / \mathrm{m}^{2} / \mathrm{d}\right)\end{array}$ & $\begin{array}{c}\text { Gd Rate } \\
\text { Error } \\
\left(\mathrm{g} / \mathrm{m}^{2} / \mathbf{d}\right)\end{array}$ & $\begin{array}{l}\text { Average } \\
\text { Ce Rate } \\
\left(\mathrm{g} / \mathrm{m}^{2} / \mathbf{d}\right)\end{array}$ & $\begin{array}{c}\text { Ce Rate } \\
\text { Error } \\
\left(\mathrm{g} / \mathrm{m}^{2} / \mathbf{d}\right)\end{array}$ & $\begin{array}{l}\text { Average } \\
\text { Ti Rate } \\
\left(\mathrm{g} / \mathrm{m}^{2} / \mathbf{d}\right)\end{array}$ & $\begin{array}{c}\text { Ti Rate } \\
\text { Error } \\
\left(\mathrm{g} / \mathrm{m}^{2} / \mathbf{d}\right)\end{array}$ & $\begin{array}{l}\text { Average } \\
\text { Ca Rate } \\
\left(\mathrm{g} / \mathrm{m}^{2} / \mathrm{d}\right)\end{array}$ & $\begin{array}{c}\text { Ca Rate } \\
\text { Error } \\
\left(\mathrm{g} / \mathrm{m}^{2} / \mathbf{d}\right)\end{array}$ & Notes \\
\hline 33 & $\begin{array}{c}1.01 \mathrm{E}-03 \\
-3.00\end{array}$ & $(2.31 \mathrm{E}-04)$ & $\begin{array}{c}1.05 \mathrm{E}-03 \\
-2.98\end{array}$ & $(2.41 \mathrm{E}-04)$ & $\begin{array}{c}1.17 \mathrm{E}-05 \\
-4.93\end{array}$ & $(2.67 \mathrm{E}-06)$ & $\begin{array}{c}2.93 \mathrm{E}-03 \\
-2.53\end{array}$ & $(6.71 \mathrm{E}-04)$ & 1 \\
\hline 34 & $\begin{array}{c}7.09 \mathrm{E}-04 \\
-3.15\end{array}$ & $(1.62 \mathrm{E}-04)$ & $\begin{array}{c}1.14 \mathrm{E}-03 \\
-2.94\end{array}$ & $(2.62 \mathrm{E}-04)$ & $\begin{array}{c}1.36 \mathrm{E}-05 \\
-4.87\end{array}$ & $(3.12 \mathrm{E}-06)$ & $\begin{array}{c}3.13 \mathrm{E}-03 \\
-2.50\end{array}$ & $(7.18 \mathrm{E}-04)$ & 1 \\
\hline 35 & $\begin{array}{c}1.05 \mathrm{E}-03 \\
-2.98\end{array}$ & $(2.41 \mathrm{E}-04)$ & $\begin{array}{c}1.35 \mathrm{E}-03 \\
-2.87\end{array}$ & (3.09E-04) & $\begin{array}{c}1.56 \mathrm{E}-05 \\
-4.81\end{array}$ & $(3.58 \mathrm{E}-06)$ & $\begin{array}{c}2.75 \mathrm{E}-03 \\
-2.56\end{array}$ & (6.30E-04) & 1 \\
\hline 36 & $\begin{array}{c}1.04 \mathrm{E}-03 \\
-2.98\end{array}$ & $(2.38 \mathrm{E}-04)$ & $\begin{array}{c}1.07 \mathrm{E}-03 \\
-2.97\end{array}$ & $(2.46 \mathrm{E}-04)$ & $\begin{array}{c}2.40 \mathrm{E}-05 \\
-4.62\end{array}$ & $(5.50 \mathrm{E}-06)$ & $\begin{array}{c}2.07 \mathrm{E}-03 \\
-2.68\end{array}$ & $(4.74 \mathrm{E}-04)$ & 1 \\
\hline 77 & $\begin{array}{c}1.42 \mathrm{E}-03 \\
-2.85\end{array}$ & $(3.25 \mathrm{E}-04)$ & $\begin{array}{c}1.45 \mathrm{E}-03 \\
-2.84\end{array}$ & (3.32E-04) & $\begin{array}{c}6.48 \mathrm{E}-05 \\
-4.19\end{array}$ & $(1.48 \mathrm{E}-05)$ & $\begin{array}{c}3.62 \mathrm{E}-03 \\
-2.44\end{array}$ & $(8.29 \mathrm{E}-04)$ & 1 \\
\hline 78 & $\begin{array}{c}1.12 \mathrm{E}-03 \\
-2.95\end{array}$ & $(2.56 \mathrm{E}-04)$ & $\begin{array}{c}1.26 \mathrm{E}-03 \\
-2.90\end{array}$ & $(2.88 \mathrm{E}-04)$ & $\begin{array}{c}13 \mathrm{E}-04 \\
-3.95\end{array}$ & $(2.59 \mathrm{E}-05)$ & $\begin{array}{c}2.35 \mathrm{E}-03 \\
-2.63\end{array}$ & $(5.39 \mathrm{E}-04)$ & 1 \\
\hline 79 & $\begin{array}{c}9.50 \mathrm{E}-04 \\
-3.02\end{array}$ & $(2.18 \mathrm{E}-04)$ & $\begin{array}{c}9.67 \mathrm{E}-04 \\
-3.01\end{array}$ & $(2.22 \mathrm{E}-04)$ & $\begin{array}{c}1.82 \mathrm{E}-04 \\
-3.74\end{array}$ & $(4.18 \mathrm{E}-05)$ & $\begin{array}{c}2.00 \mathrm{E}-03 \\
-2.70\end{array}$ & $(4.59 \mathrm{E}-04)$ & 1 \\
\hline 80 & $\begin{array}{c}8.32 \mathrm{E}-04 \\
-3.08\end{array}$ & $(1.91 \mathrm{E}-04)$ & $\begin{array}{c}8.85 \mathrm{E}-04 \\
-3.05\end{array}$ & $(2.03 \mathrm{E}-04)$ & $\begin{array}{c}2.44 \mathrm{E}-04 \\
-3.61\end{array}$ & $(5.59 \mathrm{E}-05)$ & $\begin{array}{c}5.00 \mathrm{E}-04 \\
-3.30\end{array}$ & $(1.15 \mathrm{E}-04)$ & 1 \\
\hline 43 & $\begin{array}{c}3.55 \mathrm{E}-03 \\
-2.45\end{array}$ & $(8.14 \mathrm{E}-04)$ & $\begin{array}{c}4.74 \mathrm{E}-03 \\
-2.32\end{array}$ & $(1.09 \mathrm{E}-03)$ & $\begin{array}{c}9.71 \mathrm{E}-05 \\
-4.01\end{array}$ & $(2.23 \mathrm{E}-05)$ & $\begin{array}{c}7.26 \mathrm{E}-02 \\
-1.14\end{array}$ & $(1.66 \mathrm{E}-02)$ & $\mathrm{M}$ \\
\hline 44 & $\begin{array}{c}3.47 \mathrm{E}-03 \\
-2.46\end{array}$ & $(7.95 \mathrm{E}-04)$ & $\begin{array}{c}4.66 \mathrm{E}-03 \\
-2.33\end{array}$ & $(1.07 \mathrm{E}-03)$ & $\begin{array}{c}1.01 \mathrm{E}-04 \\
-4.00\end{array}$ & $(2.32 \mathrm{E}-05)$ & $\begin{array}{c}7.00 \mathrm{E}-02 \\
-1.15\end{array}$ & $(1.60 \mathrm{E}-02)$ & $\mathrm{M}$ \\
\hline 83 & $\begin{array}{c}8.82 \mathrm{E}-03 \\
-2.05\end{array}$ & $(2.02 \mathrm{E}-03)$ & $\begin{array}{c}7.08 \mathrm{E}-03 \\
-2.15\end{array}$ & $(1.62 \mathrm{E}-03)$ & & & & & $\mathrm{M}$ \\
\hline 84 & $\begin{array}{c}1.35 \mathrm{E}-02 \\
-1.87\end{array}$ & $(3.10 \mathrm{E}-03)$ & $\begin{array}{c}9.76 \mathrm{E}-03 \\
-2.01\end{array}$ & $(2.24 \mathrm{E}-03)$ & & & & & $\mathrm{M}$ \\
\hline
\end{tabular}

Notes: 1 = powdered specimen with a specific surface area of $0.128 \mathrm{~m}^{2} \mathrm{~g}^{-1} . \mathrm{M}=$ monolithic specimen. The value of the log of the rate is given below the decimal value. Blanks indicate that rate could not be determined due to analyte concentration not measured. 
Table A.14. Steady-State Dissolution Rates and Associated 1 $\sigma$-Error for Brannerite Ceramics

\begin{tabular}{|c|c|c|c|c|c|c|c|c|c|}
\hline $\begin{array}{l}\text { HCBLx } \\
\text { Expt. \# }\end{array}$ & $\begin{array}{l}\text { Average } \\
\text { Gd Rate } \\
\left(\mathrm{g} / \mathrm{m}^{2} / \mathbf{d}\right)\end{array}$ & $\begin{array}{c}\text { Gd Rate } \\
\text { Error } \\
\left(\mathrm{g} / \mathrm{m}^{2} / \mathrm{d}\right)\end{array}$ & $\begin{array}{l}\text { Average } \\
\text { Ce Rate } \\
\left(\mathrm{g} / \mathrm{m}^{2} / \mathrm{d}\right)\end{array}$ & $\begin{array}{c}\text { Ce Rate } \\
\text { Error } \\
\left(\mathrm{g} / \mathrm{m}^{2} / \mathrm{d}\right)\end{array}$ & $\begin{array}{c}\text { Average } \\
\text { Ti Rate } \\
\left(\mathrm{g} / \mathrm{m}^{2} / \mathbf{d}\right)\end{array}$ & $\begin{array}{c}\text { Ti Rate } \\
\text { Error } \\
\left(\mathrm{g} / \mathrm{m}^{2} / \mathrm{d}\right)\end{array}$ & $\begin{array}{l}\text { Average } \\
\text { Ca Rate } \\
\left(\mathrm{g} / \mathrm{m}^{2} / \mathbf{d}\right)\end{array}$ & $\begin{array}{c}\text { Ca Rate } \\
\text { Error } \\
\left(\mathrm{g} / \mathrm{m}^{2} / \mathrm{d}\right)\end{array}$ & Notes \\
\hline 47 & & & $\begin{array}{c}6.93 \mathrm{E}-03 \\
-2.16\end{array}$ & $(1.66 \mathrm{E}-03)$ & $\begin{array}{c}5.49 \mathrm{E}-04 \\
-3.26\end{array}$ & $(1.32 \mathrm{E}-04)$ & & & M \\
\hline 51 & & & $\begin{array}{c}7.31 \mathrm{E}-02 \\
-1.14\end{array}$ & $(1.68 \mathrm{E}-02)$ & $\begin{array}{c}2.07 \mathrm{E}-03 \\
-2.68\end{array}$ & $(4.77 \mathrm{E}-04)$ & & & $\mathrm{M}$ \\
\hline 87 & & & $\begin{array}{c}4.74 \mathrm{E}-03 \\
-2.32\end{array}$ & (1.09E-03) & & & & & $\mathrm{M}$ \\
\hline 88 & & & $\begin{array}{c}8.29 \mathrm{E}-03 \\
-2.08\end{array}$ & $(1.90 \mathrm{E}-03)$ & & & & & $\mathrm{M}$ \\
\hline
\end{tabular}

Notes: 1 = powdered specimen with a specific surface area of $0.128 \mathrm{~m}^{2} \mathrm{~g}^{-1} . \mathrm{M}=$ monolithic specimen. The value of the log of the rate is given below the decimal value. Blanks indicate that rate could not be determined due to analyte concentration not measured.

Table A.15. Steady-State Dissolution Rates and Associated 1 $\sigma$-Error for "Pure-Phase" Pyrochlore Ceramics

\begin{tabular}{|c|c|c|c|c|c|c|c|c|c|}
\hline $\begin{array}{l}\text { PY-17 } \\
\text { Expt. \# }\end{array}$ & $\begin{array}{l}\text { Average } \\
\text { Gd Rate } \\
\left(\mathrm{g} / \mathrm{m}^{2} / \mathrm{d}\right)\end{array}$ & $\begin{array}{c}\text { Gd Rate } \\
\text { Error } \\
\left(\mathrm{g} / \mathrm{m}^{2} / \mathrm{d}\right)\end{array}$ & $\begin{array}{l}\text { Average } \\
\text { Ce Rate } \\
\left(\mathrm{g} / \mathrm{m}^{2} / \mathbf{d}\right)\end{array}$ & $\begin{array}{c}\text { Ce Rate } \\
\text { Error } \\
\left(\mathrm{g} / \mathrm{m}^{2} / \mathrm{d}\right)\end{array}$ & $\begin{array}{c}\text { Average } \\
\text { Ti Rate } \\
\left(\mathrm{g} / \mathrm{m}^{2} / \mathrm{d}\right)\end{array}$ & $\begin{array}{c}\text { Ti Rate } \\
\text { Error } \\
\left(\mathrm{g} / \mathrm{m}^{2} / \mathrm{d}\right)\end{array}$ & $\begin{array}{l}\text { Average } \\
\text { Ca Rate } \\
\left(\mathrm{g} / \mathrm{m}^{2} / \mathrm{d}\right)\end{array}$ & $\begin{array}{c}\text { Ca Rate } \\
\text { Error } \\
\left(\mathrm{g} / \mathrm{m}^{2} / \mathrm{d}\right)\end{array}$ & Notes \\
\hline 49 & $\begin{array}{c}8.58 \mathrm{E}-03 \\
-2.07\end{array}$ & $(2.79 \mathrm{E}-03)$ & $\begin{array}{c}1.50 \mathrm{E}-02 \\
-1.83\end{array}$ & $(4.87 \mathrm{E}-03)$ & $\begin{array}{c}3.94 \mathrm{E}-03 \\
-2.41\end{array}$ & $(1.28 \mathrm{E}-03)$ & & & M \\
\hline $17 \mathrm{~A}$ & $\begin{array}{c}3.96 \mathrm{E}-03 \\
\mathbf{- 2 . 4 0}\end{array}$ & $(9.08 \mathrm{E}-04)$ & $\begin{array}{c}5.27 \mathrm{E}-03 \\
\mathbf{- 2 . 2 8}\end{array}$ & $(1.21 \mathrm{E}-03)$ & $\begin{array}{c}2.70 \mathrm{E}-03 \\
-2.57\end{array}$ & (6.18E-04) & & & $\mathrm{M}$ \\
\hline 17B & $\begin{array}{c}4.40 \mathrm{E}-03 \\
\mathbf{- 2 . 3 6}\end{array}$ & $(1.01 \mathrm{E}-03)$ & $\begin{array}{c}5.64 \mathrm{E}-03 \\
\mathbf{- 2 . 2 5}\end{array}$ & $(1.29 \mathrm{E}-03)$ & $\begin{array}{c}3.10 \mathrm{E}-03 \\
-2.51\end{array}$ & $(7.10 \mathrm{E}-04)$ & & & $\bar{M}$ \\
\hline 91 & $\begin{array}{c}1.96 \mathrm{E}-03 \\
-2.71\end{array}$ & $(4.50 \mathrm{E}-04)$ & $\begin{array}{c}2.22 \mathrm{E}-03 \\
-2.65\end{array}$ & $(5.09 \mathrm{E}-04)$ & & & & & $\mathrm{M}$ \\
\hline 35 & $\begin{array}{c}3.64 \mathrm{E}-03 \\
\mathbf{- 2 . 4 4}\end{array}$ & $(8.34 \mathrm{E}-04)$ & $\begin{array}{c}3.91 \mathrm{E}-03 \\
\mathbf{- 2 . 4 1}\end{array}$ & $(8.97 \mathrm{E}-04)$ & & & & & $\mathrm{M}$ \\
\hline
\end{tabular}

Notes: $1=$ powdered specimen with a specific surface area of $0.128 \mathrm{~m}^{2} \mathrm{~g}^{-1} . \mathrm{M}=$ monolithic specimen. The value of the log of the rate is given below the decimal value. Blanks indicate that rate could not be determined due to analyte concentration not measured. 
Table A.16. Steady-State Dissolution Rates and Associated 1 $\sigma$-Error for Pyrochlore Baseline Ceramics

\begin{tabular}{|c|c|c|c|c|c|c|c|c|c|}
\hline $\begin{array}{l}\text { HBAS-6 } \\
\text { Expt. \# }\end{array}$ & $\begin{array}{l}\text { Average } \\
\text { Gd Rate } \\
\left(\mathrm{g} / \mathrm{m}^{2} / \mathrm{d}\right)\end{array}$ & $\begin{array}{c}\text { Gd Rate } \\
\text { Error } \\
\left(\mathrm{g} / \mathrm{m}^{2} / \mathbf{d}\right)\end{array}$ & $\begin{array}{l}\text { Average } \\
\text { Ce Rate } \\
\left(\mathrm{g} / \mathrm{m}^{2} / \mathrm{d}\right)\end{array}$ & $\begin{array}{c}\text { Ce Rate } \\
\text { Error } \\
\left(\mathrm{g} / \mathrm{m}^{2} / \mathrm{d}\right)\end{array}$ & $\begin{array}{c}\text { Average } \\
\text { Ti Rate } \\
\left(\mathrm{g} / \mathrm{m}^{2} / \mathrm{d}\right)\end{array}$ & $\begin{array}{c}\text { Ti Rate } \\
\text { Error } \\
\left(\mathrm{g} / \mathrm{m}^{2} / \mathrm{d}\right)\end{array}$ & $\begin{array}{l}\text { Average } \\
\text { Ca Rate } \\
\left(\mathrm{g} / \mathrm{m}^{2} / \mathrm{d}\right)\end{array}$ & $\begin{array}{c}\text { Ca Rate } \\
\text { Error } \\
\left(\mathrm{g} / \mathrm{m}^{2} / \mathrm{d}\right)\end{array}$ & Notes \\
\hline 46 & $\begin{array}{c}\text { 9.47E-03 } \\
-2.02\end{array}$ & $(2.17 \mathrm{E}-03)$ & \begin{tabular}{|c}
$5.45 \mathrm{E}-03$ \\
-2.26
\end{tabular} & $(1.25 \mathrm{E}-03)$ & $\begin{array}{c}\text { 3.75E-03 } \\
-2.43\end{array}$ & $(8.60 \mathrm{E}-04)$ & $\begin{array}{c}1.05 E+00 \\
0.02\end{array}$ & $(2.40 \mathrm{E}-01)$ & $\mathbf{M}$ \\
\hline 34 & \begin{tabular}{|c|}
$8.40 \mathrm{E}-03$ \\
-2.08
\end{tabular} & $(2.80 \mathrm{E}-03)$ & \begin{tabular}{|c|}
$1.33 \mathrm{E}-02$ \\
-1.88 \\
\end{tabular} & \begin{tabular}{|c|}
$(4.43 \mathrm{E}-03)$ \\
\end{tabular} & $\begin{array}{c}7.48 \mathrm{E}-03 \\
-2.13\end{array}$ & $(2.49 \mathrm{E}-03)$ & $\begin{array}{c}1.32 \mathrm{E}+00 \\
0.12\end{array}$ & $(4.41 \mathrm{E}-01)$ & $\mathbf{M}$ \\
\hline 89 & $\begin{array}{c}\text { 5.02E-03 } \\
-2.30\end{array}$ & $(1.15 \mathrm{E}-03)$ & \begin{tabular}{|c|}
$4.31 \mathrm{E}-03$ \\
-2.37
\end{tabular} & \begin{tabular}{|c|}
$(9.88 E-04)$ \\
\end{tabular} & & & & & $\mathbf{M}$ \\
\hline 36 & $\begin{array}{c}6.07 \mathrm{E}-03 \\
-2.22\end{array}$ & $(1.39 \mathrm{E}-03)$ & \begin{tabular}{|c|}
$5.21 \mathrm{E}-03$ \\
-2.28
\end{tabular} & 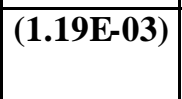 & & & & & $\mathbf{M}$ \\
\hline
\end{tabular}

Notes: 1 = powdered specimen with a specific surface area of $0.128 \mathrm{~m}^{2} \mathrm{~g}^{-1} . \mathrm{M}=$ monolithic specimen. The value of the log of the rate is given below the decimal value. Blanks indicate that rate could not be determined due to analyte concentration not measured.

Table A.17. Steady-State Dissolution Rates and Associated 1 $\sigma$-Error for Zirconolite Ceramics

\begin{tabular}{|c||c|c|c|c|c|c|c|c|c||}
\hline HZirc5x & $\begin{array}{c}\text { Average } \\
\text { Gd Rate } \\
\text { Expt. \# } \\
\left(\mathbf{g} / \mathbf{m}^{2} / \mathbf{d}\right)\end{array}$ & $\begin{array}{c}\text { Gd Rate } \\
\text { Error } \\
\left(\mathbf{g} / \mathbf{m}^{2} / \mathbf{d}\right)\end{array}$ & $\begin{array}{c}\text { Average } \\
\text { Ce Rate } \\
\left(\mathbf{g} / \mathbf{m}^{2} / \mathbf{d}\right)\end{array}$ & $\begin{array}{c}\text { Ce Rate } \\
\text { Error } \\
\left(\mathbf{g} / \mathbf{m}^{2} / \mathbf{d}\right)\end{array}$ & $\begin{array}{c}\text { Average } \\
\mathbf{T i} \text { Rate } \\
\left(\mathbf{g} / \mathbf{m}^{2} / \mathbf{d}\right)\end{array}$ & $\begin{array}{c}\text { Ti Rate } \\
\text { Error } \\
\left(\mathbf{g} / \mathbf{m}^{2} / \mathbf{d}\right)\end{array}$ & $\begin{array}{c}\text { Average } \\
\text { Ca Rate } \\
\left(\mathbf{g} / \mathbf{m}^{2} / \mathbf{d}\right)\end{array}$ & $\begin{array}{c}\text { Ca Rate } \\
\text { Error } \\
\left(\mathbf{g} / \mathbf{m}^{2} / \mathbf{d}\right)\end{array}$ & $\mathbf{~ N o t e s}$ \\
\hline \hline \multirow{2}{*}{48} & $\begin{array}{c}1.86 \mathrm{E}-03 \\
-2.73\end{array}$ & $(4.33 \mathrm{E}-04)$ & $\begin{array}{c}4.54 \mathrm{E}-03 \\
-2.34\end{array}$ & $(1.05 \mathrm{E}-03)$ & $\begin{array}{c}1.74 \mathrm{E}-04 \\
-3.76\end{array}$ & $(4.04 \mathrm{E}-05)$ & $\begin{array}{c}4.80 \mathrm{E}-03 \\
-2.32\end{array}$ & $(1.12 \mathrm{E}-03)$ & $\mathrm{M}$ \\
\hline 34 & $\begin{array}{c}1.90 \mathrm{E}-03 \\
-2.72\end{array}$ & $(4.42 \mathrm{E}-04)$ & $\begin{array}{c}5.38 \mathrm{E}-03 \\
-2.27\end{array}$ & $(1.25 \mathrm{E}-03)$ & $\begin{array}{c}3.24 \mathrm{E}-04 \\
-3.49\end{array}$ & $(7.55 \mathrm{E}-05)$ & & & $\mathrm{M}$ \\
\hline 85 & $\begin{array}{c}1.46 \mathrm{E}-03 \\
-2.84\end{array}$ & $(3.36 \mathrm{E}-04)$ & $\begin{array}{c}3.40 \mathrm{E}-03 \\
-2.47\end{array}$ & $(7.83 \mathrm{E}-04)$ & & & & & $\mathrm{M}$ \\
\hline 86 & $\begin{array}{c}1.70 \mathrm{E}-03 \\
-2.77\end{array}$ & $(3.92 \mathrm{E}-04)$ & $\begin{array}{c}4.58 \mathrm{E}-03 \\
-2.34\end{array}$ & $(1.06 \mathrm{E}-03)$ & & & & & $\mathrm{M}$ \\
\hline
\end{tabular}

Notes: $1=$ powdered specimen with a specific surface area of $0.128 \mathrm{~m}^{2} \mathrm{~g}^{-1} . \mathrm{M}=$ monolithic specimen. The value of the log of the rate is given below the decimal value. Blanks indicate that rate could not be determined due to analyte concentration not measured. 
Table A.18. Steady-State Dissolution Rates and Associated $1 \sigma$-Error for ${ }^{238}$ Pu-Bearing Pyrochlore Baseline Ceramics

\begin{tabular}{|c|c|c|c|c|c|c|c|c|c|}
\hline $\begin{array}{c}\text { 238-Pbas } \\
\text { Expt. \# }\end{array}$ & $\begin{array}{l}\text { Average } \\
\text { Gd Rate } \\
\left(\mathrm{g} / \mathrm{m}^{2} / \mathrm{d}\right)\end{array}$ & $\begin{array}{c}\text { Gd Rate } \\
\text { Error } \\
\left(\mathrm{g} / \mathrm{m}^{2} / \mathrm{d}\right)\end{array}$ & $\begin{array}{c}\text { Average } \\
\text { U Rate } \\
\left(\mathrm{g} / \mathrm{m}^{2} / \mathrm{d}\right)\end{array}$ & $\begin{array}{c}\text { U Rate } \\
\text { Error } \\
\left(\mathrm{g} / \mathrm{m}^{2} / \mathrm{d}\right)\end{array}$ & $\begin{array}{c}\text { Average } \\
\text { Ti Rate } \\
\left(\mathrm{g} / \mathrm{m}^{2} / \mathrm{d}\right)\end{array}$ & $\begin{array}{c}\text { Ti Rate } \\
\text { Error } \\
\left(\mathrm{g} / \mathrm{m}^{2} / \mathrm{d}\right)\end{array}$ & $\begin{array}{l}\text { Average } \\
\text { Pu Rate } \\
\left(\mathrm{g} / \mathrm{m}^{2} / \mathrm{d}\right)\end{array}$ & $\begin{array}{c}\text { Pu Rate } \\
\text { Error } \\
\left(\mathrm{g} / \mathrm{m}^{2} / \mathrm{d}\right)\end{array}$ & Notes \\
\hline $239-1$ & $\begin{array}{c}1.99 \mathrm{E}-04 \\
-3.70\end{array}$ & $(4.58 \mathrm{E}-05)$ & $\begin{array}{c}8.17 \mathrm{E}-03 \\
-2.09\end{array}$ & $(1.88 \mathrm{E}-03)$ & $\begin{array}{c}3.19 \mathrm{E}-05 \\
-4.50\end{array}$ & $(7.33 \mathrm{E}-06)$ & $\begin{array}{c}1.13 \mathrm{E}-02 \\
-1.95\end{array}$ & $(2.60 \mathrm{E}-03)$ & 1 \\
\hline
\end{tabular}

Notes: 1 = powdered specimen with a specific surface area of $0.128 \mathrm{~m}^{2} \mathrm{~g}^{-1} . \mathrm{M}=$ monolithic specimen. The value of the log of the rate is given below the decimal value. Blanks indicate that rate could not be determined due to analyte concentration not measured.

Table A.19. Steady-State Dissolution Rates and Associated 1 $\sigma$-Error for Zirconolite Ceramics

\begin{tabular}{|c|c|c|c|c|c|c|c|c|c|}
\hline $\begin{array}{l}\text { CeZirc6 } \\
\text { Expt. \# }\end{array}$ & $\begin{array}{l}\text { Average } \\
\text { Gd Rate } \\
\left(\mathrm{g} / \mathrm{m}^{2} / \mathrm{d}\right)\end{array}$ & $\begin{array}{c}\text { Gd Rate } \\
\text { Error } \\
\left(\mathrm{g} / \mathrm{m}^{2} / \mathbf{d}\right)\end{array}$ & $\begin{array}{l}\text { Average } \\
\text { Ce Rate } \\
\left(\mathrm{g} / \mathrm{m}^{2} / \mathrm{d}\right)\end{array}$ & $\begin{array}{c}\text { Ce Rate } \\
\text { Error } \\
\left(\mathrm{g} / \mathrm{m}^{2} / \mathbf{d}\right)\end{array}$ & $\begin{array}{c}\text { Average } \\
\text { Ti Rate } \\
\left(\mathrm{g} / \mathrm{m}^{2} / \mathrm{d}\right)\end{array}$ & $\begin{array}{c}\text { Ti Rate } \\
\text { Error } \\
\left(\mathrm{g} / \mathrm{m}^{2} / \mathbf{d}\right)\end{array}$ & $\begin{array}{c}\text { Average } \\
\text { Mo Rate } \\
\left(\mathrm{g} / \mathrm{m}^{2} / \mathrm{d}\right)\end{array}$ & $\begin{array}{c}\text { Mo Rate } \\
\text { Error } \\
\left(\mathrm{g} / \mathrm{m}^{2} / \mathbf{d}\right)\end{array}$ & Notes \\
\hline 57 & $\begin{array}{c}5.36 \mathrm{E}-06 \\
-5.27\end{array}$ & $(1.24 \mathrm{E}-06)$ & $\begin{array}{c}2.53 \mathrm{E}-05 \\
-4.60\end{array}$ & $(5.85 \mathrm{E}-06)$ & $\begin{array}{c}3.56 \mathrm{E}-07 \\
-6.45\end{array}$ & $(8.23 \mathrm{E}-08)$ & & & $\begin{array}{c}\text { Ca rate }= \\
4.86 \mathrm{E}-05 \\
-4.31\end{array}$ \\
\hline 59 & & & & & & & \begin{tabular}{|c|}
$2.23 \mathrm{E}-04$ \\
-3.65 \\
\end{tabular} & $(5.16 \mathrm{E}-05)$ & 1 \\
\hline 61 & & & & & & & \begin{tabular}{|c|}
$7.88 \mathrm{E}-05$ \\
-4.10
\end{tabular} & (1.93E-05) & 1 \\
\hline 62 & & & & & & & \begin{tabular}{|c|}
$7.53 \mathrm{E}-05$ \\
-4.12
\end{tabular} & $(1.78 \mathrm{E}-05)$ & 1 \\
\hline 63 & & & & & & & \begin{tabular}{|c|}
$1.04 \mathrm{E}-04$ \\
-3.98
\end{tabular} & $(2.44 \mathrm{E}-05)$ & 1 \\
\hline
\end{tabular}

Notes: $1=$ powdered specimen with a specific surface area of $0.128 \mathrm{~m}^{2} \mathrm{~g}^{-1} . \mathrm{M}=$ monolithic specimen. The value of the log of the rate is given below the decimal value. Blanks indicate that rate could not be determined due to analyte concentration not measured. 
Table A.20. Steady-State Dissolution Rates and Associated $1 \sigma$-Error for ${ }^{239}$ Pu-Bearing Zirconolite Ceramics

\begin{tabular}{|c|c|c|c|c|c|c|c|c|c|}
\hline $\begin{array}{l}\text { Zirc-1 } \\
\text { Expt. \# }\end{array}$ & $\begin{array}{l}\text { Average } \\
\text { Gd Rate } \\
\left(\mathrm{g} / \mathrm{m}^{2} / \mathrm{d}\right)\end{array}$ & $\begin{array}{c}\text { Gd Rate } \\
\text { Error } \\
\left(\mathrm{g} / \mathrm{m}^{2} / \mathbf{d}\right)\end{array}$ & $\begin{array}{c}\text { Average } \\
\text { U Rate } \\
\left(\mathrm{g} / \mathrm{m}^{2} / \mathbf{d}\right)\end{array}$ & $\begin{array}{c}\text { U Rate } \\
\text { Error } \\
\left(\mathrm{g} / \mathrm{m}^{2} / \mathrm{d}\right)\end{array}$ & $\begin{array}{c}\text { Average } \\
\text { Ti Rate } \\
\left(\mathrm{g} / \mathrm{m}^{2} / \mathrm{d}\right)\end{array}$ & $\begin{array}{c}\text { Ti Rate } \\
\text { Error } \\
\left(\mathrm{g} / \mathrm{m}^{2} / \mathrm{d}\right)\end{array}$ & $\begin{array}{c}\text { Average } \\
\text { Mo Rate } \\
\left(\mathrm{g} / \mathrm{m}^{2} / \mathrm{d}\right)\end{array}$ & $\begin{array}{c}\text { Mo Rate } \\
\text { Error } \\
\left(\mathrm{g} / \mathrm{m}^{2} / \mathbf{d}\right)\end{array}$ & Notes \\
\hline 1 & $\begin{array}{c}3.91 \mathrm{E}-05 \\
-4.41\end{array}$ & (8.97E-06) & $\begin{array}{c}7.56 \mathrm{E}-05 \\
-4.12\end{array}$ & $(1.73 \mathrm{E}-05)$ & $\begin{array}{c}1.64 \mathrm{E}-05 \\
-4.78\end{array}$ & $(3.76 \mathrm{E}-06)$ & $\begin{array}{c}7.40 \mathrm{E}-05 \\
-4.13\end{array}$ & $(1.69 \mathrm{E}-05)$ & 1 \\
\hline 2 & & & $\begin{array}{c}2.62 \mathrm{E}-04 \\
-3.58\end{array}$ & $(6.01 \mathrm{E}-05)$ & $\begin{array}{c}2.36 \mathrm{E}-07 \\
-6.63\end{array}$ & $(5.42 \mathrm{E}-08)$ & $\begin{array}{c}2.09 \mathrm{E}-04 \\
-3.68\end{array}$ & $(4.80 \mathrm{E}-05)$ & 1 \\
\hline 3 & & & $\begin{array}{c}1.51 \mathrm{E}-04 \\
-3.82\end{array}$ & $(3.55 \mathrm{E}-05)$ & $\begin{array}{c}3.11 \mathrm{E}-07 \\
-6.51\end{array}$ & $(7.32 \mathrm{E}-08)$ & $\begin{array}{c}1.73 \mathrm{E}-04 \\
-3.76\end{array}$ & $(4.07 \mathrm{E}-05)$ & 1 \\
\hline 4 & & & $\begin{array}{c}2.27 \mathrm{E}-04 \\
-3.64\end{array}$ & $(5.53 \mathrm{E}-05)$ & $\begin{array}{c}2.08 \mathrm{E}-07 \\
-6.68\end{array}$ & $(5.07 \mathrm{E}-08)$ & $\begin{array}{c}8.54 \mathrm{E}-05 \\
-4.07\end{array}$ & $(2.08 \mathrm{E}-05)$ & 1 \\
\hline 5 & & & $\begin{array}{c}5.00 \mathrm{E}-04 \\
-3.30\end{array}$ & $(0.00 \mathrm{E}+00)$ & $\begin{array}{c}3.17 \mathrm{E}-07 \\
-6.50\end{array}$ & $(0.00 \mathrm{E}+00)$ & $\begin{array}{c}7.35 \mathrm{E}-05 \\
-4.13\end{array}$ & $(0.00 \mathrm{E}+00)$ & 1 \\
\hline 6 & & & $\begin{array}{c}9.57 \mathrm{E}-05 \\
-4.02\end{array}$ & $(0.00 \mathrm{E}+00)$ & $\begin{array}{c}2.18 \mathrm{E}-07 \\
-6.66\end{array}$ & $(0.00 \mathrm{E}+00)$ & $\begin{array}{c}1.64 \mathrm{E}-05 \\
-4.79\end{array}$ & $(0.00 \mathrm{E}+00)$ & 1 \\
\hline 7 & & & $\begin{array}{c}2.00 \mathrm{E}-04 \\
-3.70\end{array}$ & $(4.65 \mathrm{E}-05)$ & $\begin{array}{c}1.75 \mathrm{E}-07 \\
-6.76\end{array}$ & $(4.06 \mathrm{E}-08)$ & $\begin{array}{c}3.18 \mathrm{E}-05 \\
-4.50\end{array}$ & $(7.40 \mathrm{E}-06)$ & 1 \\
\hline
\end{tabular}

Notes: 1 = powdered specimen with a specif ic surface area of $0.128 \mathrm{~m}^{2} \mathrm{~g}^{-1} . \mathrm{M}=$ monolithic specimen. The value of the log of the rate is given below the decimal value. Blanks indicate that rate could not be determined due to analyte concentration not measured.

Table A.21. Steady-State Dissolution Rates and Associated $1 \sigma$-Error for ${ }^{238}$ Pu-Bearing Pyrochlore Baseline (annealed and un-annealed), "Pure Phase" Pyrochlore, and Zirconolite Ceramics

\begin{tabular}{|c|c|c|c|c|c|c|c|c|c|}
\hline $\begin{array}{l}\text { 238-Pu } \\
\text { Expt. \# }\end{array}$ & $\begin{array}{l}\text { Average } \\
\text { Gd Rate } \\
\left(\mathrm{g} / \mathrm{m}^{2} / \mathrm{d}\right)\end{array}$ & $\begin{array}{c}\text { Gd Rate } \\
\text { Error } \\
\left(\mathrm{g} / \mathrm{m}^{2} / \mathrm{d}\right)\end{array}$ & $\begin{array}{c}\text { Average } \\
\text { U Rate } \\
\left(\mathrm{g} / \mathbf{m}^{2} / \mathbf{d}\right)\end{array}$ & $\begin{array}{c}\text { U Rate } \\
\text { Error } \\
\left(\mathrm{g} / \mathrm{m}^{2} / \mathrm{d}\right)\end{array}$ & $\begin{array}{c}\text { Average } \\
\text { Ti Rate } \\
\left(\mathrm{g} / \mathrm{m}^{2} / \mathrm{d}\right)\end{array}$ & $\begin{array}{c}\text { Ti Rate } \\
\text { Error } \\
\left(\mathrm{g} / \mathrm{m}^{2} / \mathrm{d}\right)\end{array}$ & $\begin{array}{l}\text { Average } \\
\text { Pu Rate } \\
\left(\mathrm{g} / \mathrm{m}^{2} / \mathrm{d}\right)\end{array}$ & $\begin{array}{c}\text { Pu Rate } \\
\text { Error } \\
\left(\mathrm{g} / \mathrm{m}^{2} / \mathbf{d}\right)\end{array}$ & Notes \\
\hline $\begin{array}{c}238-2 \\
\text { Pbase-a }\end{array}$ & $\begin{array}{c}4.48 \mathrm{E}-04 \\
-3.35\end{array}$ & $(1.03 \mathrm{E}-04)$ & $\begin{array}{c}8.38 \mathrm{E}-04 \\
-3.08\end{array}$ & $(1.92 \mathrm{E}-04)$ & & & $\begin{array}{c}3.67 \mathrm{E}-04 \\
-3.44\end{array}$ & $(8.41 \mathrm{E}-05)$ & 1 \\
\hline $\begin{array}{c}238-3 \\
\text { Pbase-u }\end{array}$ & $\begin{array}{c}3.27 \mathrm{E}-04 \\
-3.49\end{array}$ & $(7.49 \mathrm{E}-05)$ & $\begin{array}{c}6.65 \mathrm{E}-04 \\
-3.18\end{array}$ & $(1.52 \mathrm{E}-04)$ & & & $\begin{array}{c}2.79 \mathrm{E}-04 \\
-3.55\end{array}$ & $(6.41 \mathrm{E}-05)$ & 1 \\
\hline $\begin{array}{c}238-1 \\
\text { Pyro-a }\end{array}$ & $\begin{array}{c}2.75 \mathrm{E}-04 \\
-3.56\end{array}$ & $(6.30 \mathrm{E}-05)$ & $\begin{array}{c}8.89 \mathrm{E}-04 \\
-3.05\end{array}$ & $(2.04 \mathrm{E}-04)$ & & & $\begin{array}{c}2.73 \mathrm{E}-04 \\
-3.56\end{array}$ & $(6.25 \mathrm{E}-05)$ & 1 \\
\hline $\begin{array}{l}238-4 \\
\text { Zirc-a }\end{array}$ & $\begin{array}{c}1.02 \mathrm{E}-03 \\
-2.99\end{array}$ & $(2.35 \mathrm{E}-04)$ & $\begin{array}{c}2.10 \mathrm{E}-02 \\
-1.68\end{array}$ & $(4.82 \mathrm{E}-03)$ & & & $\begin{array}{c}3.05 \mathrm{E}-04 \\
-3.52\end{array}$ & $(6.99 \mathrm{E}-05)$ & 1 \\
\hline
\end{tabular}

Notes: 1 = powdered specimen with a specific surface area of $0.128 \mathrm{~m}^{2} \mathrm{~g}^{-1} . \mathrm{M}=$ monolithic specimen. The value of the log of the rate is given below the decimal value. Blanks indicate that rate could not be determined due to analyte concentration not measured. 
Table A.22. Steady-State Dissolution Rates and Associated $1 \sigma$-Error for ${ }^{239}$ Pu-Bearing Pyrochlore Baseline Ceramics

\begin{tabular}{|c|c|c|c|c|c|c|c|c|c|}
\hline $\begin{array}{c}\text { 239-Pbas } \\
\text { Expt. \# }\end{array}$ & $\begin{array}{l}\text { Average } \\
\text { Gd Rate } \\
\left(\mathrm{g} / \mathrm{m}^{2} / \mathrm{d}\right)\end{array}$ & $\begin{array}{l}\text { Gd Rate } \\
\text { Error } \\
\left(\mathrm{g} / \mathbf{m}^{2} / \mathbf{d}\right)\end{array}$ & $\begin{array}{c}\text { Average } \\
\text { U Rate } \\
\left(\mathrm{g} / \mathrm{m}^{2} / \mathrm{d}\right)\end{array}$ & $\begin{array}{l}\text { U Rate } \\
\text { Error } \\
\left(\mathrm{g} / \mathrm{m}^{2} / \mathrm{d}\right)\end{array}$ & $\begin{array}{c}\text { Average } \\
\text { Ti Rate } \\
\left(\mathrm{g} / \mathrm{m}^{2} / \mathbf{d}\right)\end{array}$ & $\begin{array}{l}\text { Ti Rate } \\
\text { Error } \\
\left(\mathrm{g} / \mathrm{m}^{2} / \mathbf{d}\right)\end{array}$ & $\begin{array}{l}\text { Average } \\
\text { Pu Rate } \\
\left(\mathrm{g} / \mathrm{m}^{2} / \mathrm{d}\right)\end{array}$ & $\begin{array}{l}\text { Pu Rate } \\
\text { Error } \\
\left(\mathrm{g} / \mathrm{m}^{2} / \mathbf{d}\right)\end{array}$ & Notes \\
\hline $239-1$ & $\begin{array}{c}1.70 \mathrm{E}-05 \\
-4.77\end{array}$ & $(3.90 \mathrm{E}-06)$ & $\begin{array}{c}1.51 \mathrm{E}-05 \\
-4.82\end{array}$ & $(3.47 \mathrm{E}-06)$ & $\begin{array}{c}2.54 \mathrm{E}-06 \\
-5.59\end{array}$ & $(5.83 \mathrm{E}-07)$ & $\begin{array}{c}\text { 7.70E-06 } \\
-5.11\end{array}$ & $(1.77 \mathrm{E}-06)$ & 1 \\
\hline $239-2$ & & & $\begin{array}{c}4.35 \mathrm{E}-06 \\
-5.36\end{array}$ & $(9.97 \mathrm{E}-07)$ & & & & & 1 \\
\hline $239-3$ & & & $\begin{array}{c}2.80 \mathrm{E}-06 \\
-5.55\end{array}$ & $(6.43 \mathrm{E}-07)$ & & & & & 1 \\
\hline $239-4$ & & & $\begin{array}{c}2.71 \mathrm{E}-06 \\
-5.57\end{array}$ & $(6.22 \mathrm{E}-07)$ & & & & & 1 \\
\hline $239-5$ & & & $\begin{array}{c}2.40 \mathrm{E}-06 \\
-5.62\end{array}$ & \begin{tabular}{|c|}
$(5.51 \mathrm{E}-07)$ \\
\end{tabular} & & & & & 1 \\
\hline $239-6$ & & & $\begin{array}{c}7.54 \mathrm{E}-06 \\
-5.12\end{array}$ & $(1.73 \mathrm{E}-06)$ & & & & & 1 \\
\hline
\end{tabular}

Notes: $1=$ powdered specimen with a specific surface area of $0.128 \mathrm{~m}^{2} \mathrm{~g}^{-1} . \mathrm{M}=$ monolithic specimen. The value of the log of the rate is given below the decimal value. Blanks indicate that rate could not be determined due to analyte concentration not measured. 
PNNL-14252

\section{Distribution}

No. of

Copies

\section{OFFSITE}

2 Argonne National Laboratory

Building 205

9700 South Cass Avenue

Argonne, IL 60439-4837

Attn: David Chamberlain

Alan Bakel

2 Australian Nuclear Science and Technology

Organization

PMB 1

Menai NSW 2234

Australia

Attn: L. Vance (2)

1 Massachusetts Institute of Technology

77 Massachusetts Avenue

Cambridge, MA 02139-4307

Attn: Dr. L. W. Hobbs

1 University of Michigan Geological Sciences 1006 C Little

Ann Arbor MI 48109-1063

Attn: Dr. Rodney Ewing

1 US Department of Energy, Headquarters

Forrestal (NN-62)

1000 Independence Avenue, S.W.

Washington, DC 20585

Attn: J. Bozik

1 US Department of Energy, Headquarters

Germantown

19901 Germantown Road

Germantown, MD 20874-1290

Attn: H. F. Shaw
No. of

Copies

\section{OFFSITE}

1 Westinghouse Savannah River Company

P. O. Box 616

Aiken, SC 29802

Attn: James Marra

3 Lawrence Livermore National Laboratory

P. O. Box 808

Livermore, CA 94551

Attn: W. Bourcier

B. Ebbingh aus

R. VanKonynenberg

\section{ONSITE}

4 U.S. Department of Energy/Richland Operations Office

D. L. Biancosino K8-50

Public Reading Room H2-53

RL Docket File (2) H5-36

24 Pacific Northwest National Laboratory

J. P. Icenhower (10) K6-81

A. E. Kozelisky P7-25

M. J. Lindberg P7-22

D. E. McCready K8-93

B. P. McGrail K6-81

E. A. Rodriguez K6-81

H. T. Schaef K6-81

R. L. Sell P7-25

J. L. Steele (K6-81)

D. M. Strachan (10) K6-24

W. J. Weber K8-93

Information Release Office (2) K1-06 